\title{
WUDAPT \\ An Urban Weather, Climate, and Environmental Modeling Infrastructure for the Anthropocene
}

\author{
J. Ching, G. Mills, B. Bechtel, L. See, J. Feddema, X. Wang, C. Ren, O. Brousse, A. Martilli, \\ M. Neophytou, P. Mouzourides, I. Stewart, A. Hanna, E. Ng, M. Foley, P. Alexander, D. Aliaga, \\ D. Niyogi, A. Shreevastava, P. Bhalachandran, V. Masson, J. Hidalgo, J. Fung, M. Andrade, \\ A. Baklanov, W. Dai, G. Milcinski, M. Demuzere, N. Brunsell, M. Pesaresi, S. Miao, Q. Mu, \\ F. Chen, AND N. TheeUWes
}
WUDAPT is an international community-generated urban canopy information and modeling infrastructure to facilitate urban-focused climate, weather, air quality, and energy-use modeling application studies

\section{T} he Anthropocene epoch, the human-influenced geologic time period (Crutzen and Stoermer 2000), is linked inextricably to urbanization. Human activities in this epoch have had a demonstrable impact on climates at all scales, and without proper management, increased urbanization will contribute to associated extreme and unexpected weather events in cities. Currently, more than half of the planet's population resides in urban areas, and by 2050 , up to $75 \%$ are projected to live in cities of varying sizes (United Nations 2014). The development of ever more powerful computer models to simulate weather and climate, air quality, hydrology, and other environmental processes now allow us to evaluate the impacts of urban areas on climate processes and to assess urban vulnerabilities to natural hazards. These tools are needed to support urban management, to mitigate deleterious effects, and to support resiliency strategies but require climate relevant information on urban landscapes to be effective (Masson et al. 2014).

The effect of urbanization on the environment is an outcome of its physical form (i.e., the land cover, the materials, and the geometry of buildings) and its functions (the transportation, energy usage, and generation of waste products) that sustain human activities. These vary spatially and temporally and act in concert to adversely affect local climate, hydrology, biodiversity, and air quality. These impact the quality of life and sometimes enhance risks to public health; for example, the urban heat island (UHI) is exacerbated during heat wave events and makes city dwellers especially exposed to heat stress. It is therefore crucial to characterize as best as possible these urban properties, so to be able to predict, via modeling (Chen et al. 2011), the hazard, exposure, and vulnerabilities of urban dwellers to present and future environmental states (NRC 2012). Sustained research on urban meteorology and climate over the past 50 years has provided insights into the layering of the urban boundary layer and its links with the underlying surface (Fig. 1a). As a result, state-of-thescience numerical models can simulate the surface energy budgets, weather, climate, and air quality.

Examples include the Surface Urban Energy and Water Balance Scheme (SUEWS), the Weather Research and Forecasting (WRF) Model, the 
Community Earth System Model (CESM), and the Community Multiscale Air Quality (CMAQ) model; each of these systems continue to evolve, providing enhanced capabilities, results, and guidance at increasingly finer grid resolutions. However, these models are reliant on appropriate data that capture the spatially varying and temporally evolving characteristics of urban surfaces; Fig. 1b shows common urban canopy parameters (UCPs) that are needed by "urbanized" climate models. In North America, the National Urban Database and Access Portal Tool (NUDAPT) compiled this information for parts of more than 40 cities (Ching et al. 2009), but in most places the data to derive UCPs are either not available/incomplete and/or available at poor spatial/ temporal resolutions. The absence of internationally consistent urban data for such purposes is recognized by global-to-urban climate science communities to be a significant impediment to scientific progress (Jackson et al. 2010; Revi et al. 2014; Baklanov et al. $2009,2018)$. Overcoming this impediment is the aim of the World Urban Database and Access Portal Tool (WUDAPT) project.

In this paper, we review the concepts and operational methodologies that underpin WUDAPT (Ching 2013; Ching et al. 2016, 2017b), present some initial results, and present near-term plans. Our intent is to introduce the project and demonstrate its value to the climate community and, while individual experiments are introduced, the research details are referenced rather than discussed in detail.

WUDAPT OVERVIEW. The goals of WUDAPT are 1) to acquire and make accessible coherent and consistent descriptions and information on form and function of urban morphology relevant to climate, weather, and environment studies on a worldwide basis and 2) to provide a portal with tools that extract relevant urban parameters and properties for models and for model applications at appropriate scales for various climate, weather, environment, and urban planning purposes. Its guiding principle is to generate "fit for purpose" urban data using a globally consistent methodology using available, publicly accessible input data and tools. Products created from this process are shared across multiple communities and platforms.

The data needed to apply models successfully to cities must meet several criteria. First, the modeling description of the urban surface must permit the model to resolve the temporal and spatial characteristics of the mesoscale urban boundary layer, including properties at local scales (Fig. 1a). Second, the spatial gradients of the input (and thus the output) fields are typically highly variable across urban landscapes; consequently, any coarse model grid must represent subgrid variations (Ching 2013; Mouzourides et al. 2013 , 2014). Third, data requirements for urbanized models can be highly specialized; typically, they are distinguished by their need for UCP information on building height, vegetative cover, building materials, etc. (see Table 1 and Fig. 1b; Masson 2000; Martilli et al. 2002; Dupont et al. 2004; Otte et al. 2004; Oleson et al. 2008). Fourth, for worldwide applicability, UCPs should be collected using a scheme that is consistent and reliable. Finally, given the time frame, the generation of this database should be practicable and achievable on a reasonably short time frame for greatest impact. WUDAPT adopts a pragmatic approach to meet these criteria.

The components of the urban landscape that are relevant to climate can be organized by scale into
AfFiliations: CHING AND HANNA-Institute for the Environment, University of North Carolina at Chapel Hill, Chapel Hill, North Carolina; Mills, Foley, AND AleXander-University College Dublin, Dublin, Ireland; BECHTEL—University of Hamburg, Hamburg, Germany; SeE-IIASA, Vienna, Austria; FeddemA-University of Victoria, Victoria, British Columbia, Canada; WANG AND DAI-Sun Yat Sen University, Guangzhou, China; ReN AND NG-Chinese University of Hong Kong, Hong Kong, China; Brousse-KU Leuven, Leuven, Belgium; Martilli-CIEMAT, Madrid, Spain; Neophytou and MouzouridesUniversity of Cyprus, Nicosia, Cyprus; StEWART-University of Toronto, Toronto, Ontario, Canada; Aliaga, Niyogi, Shreevastava, AND BHALACHANDRAN-Purdue University, West Lafayette, Indiana; MASSON-Météo-France, Toulouse, France; HIDALGO-University of Toulouse II, Toulouse, France; FUNG-Hong Kong University of Science and Technology, Hong Kong, China; ANDRADE-University of São Paulo, São Paulo, Brazil; BAKLANOv—World Meteorological
Organization, Geneva, Switzerland; MILCINSKI-Sinergise, Ljubljana, Slovenia; DemUzere-Department of Forest and Water Management, Ghent University, Ghent, Belgium; BRUNSELL-University of Kansas, Lawrence, Kansas; PESARESI-JRC, European Commission, Ispra, Italy; MIAO AND Mu-Institute of Urban Meteorology, China Meteorological Administration, Beijing, China; CHEN-NCAR, Boulder, Colorado; TheEUWES-University of Reading, Reading, United Kingdom

CORRESPONDING AUTHOR: Jason Ching, jksching@gmail.com

The abstract for this article can be found in this issue, following the table of contents.

DOI:I0.II75/BAMS-D-16-0236.I

In final form 18 January 2018

(C)2018 American Meteorological Society

For information regarding reuse of this content and general copyright

information, consult the AMS Copyright Policy. 

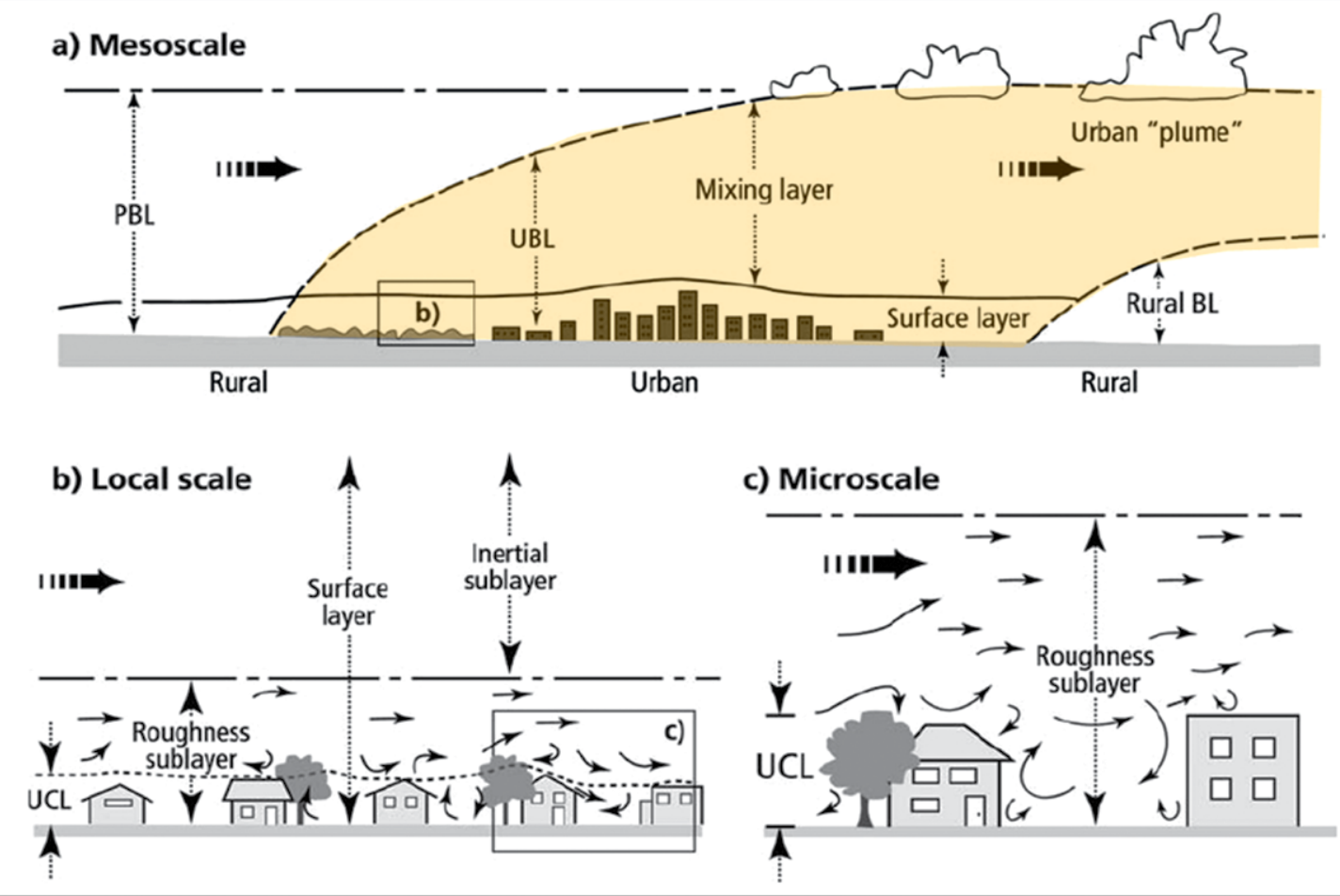

Urban cover

(a) $\lambda_{b}=A_{b} / A_{T}$

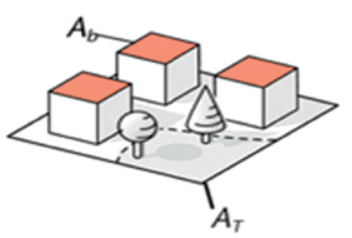

(b) $\lambda_{v}=A_{v} / A_{T}$

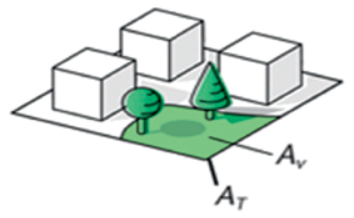

(c) $\lambda_{i}=A_{i} / A_{T}$

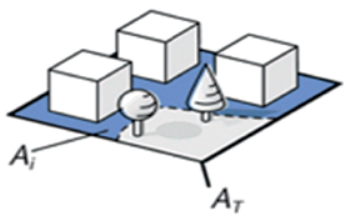

Length scales

(d) Building dimensions

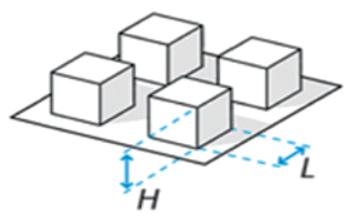

(e) Building spacing

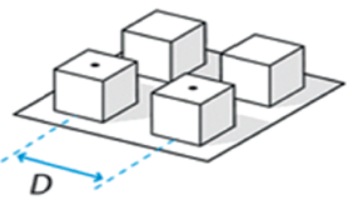

(f) $\lambda_{s}=H / W$

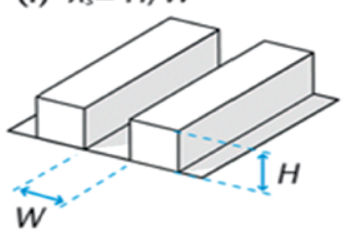

\section{Urban structure}

(g) $\lambda_{\text {floor }}=A_{\text {floor }} / A_{T}$

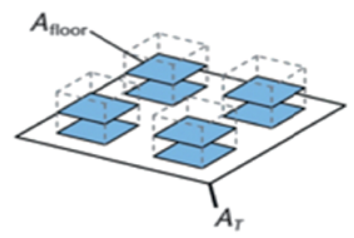

(h) $\lambda_{c}=A_{c} / A_{T}$

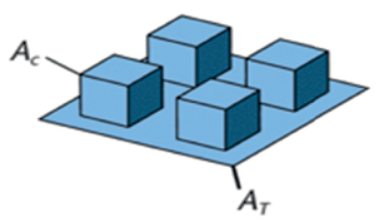

(i) $\lambda_{f}=A_{f} / A_{T}$

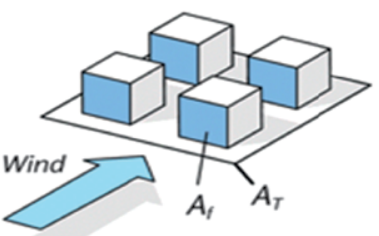

Fig. I. (top) Structure of the urban boundary layers (source: Oke 2006) showing the developing of the mixed layer above the underlying surface layer in terms of (a) mesoscale, (b) local scale, and (c) microscale, where exchanges are modulated by urban form and functions. (bottom) Common UCPs that describe the character of the urban surface and are employed in models to evaluate the urban effect on wind, temperature, runoff, etc. (courtesy Andreas Christen). 
TABLE I. Examples of UCPs used in urban models. The BEP scheme (Martilli et al. 2002) that is linked to the WRF in W2W specifically utilizes the building UCPs in column 2.

\begin{tabular}{|lll|}
\hline & \multicolumn{2}{c|}{ Urban Canopy Parameters } \\
\hline General & Buildings & Vegetation \\
\hline Mean canopy height & Mean height & Vegetation plan area density \\
Canopy plan area density & Std dev of heights & Vegetation top area density \\
Canopy top area density & Height histogram & Vegetation frontal area density \\
Canopy frontal area density & Wall-to-plan area ratio & \\
Roughness length & Height-to-width ratio & Mean orientation of streets \\
Displacement height & Plan area density & Plan area fraction surface covers \\
Sky view factor & Rooftop area density & Percent connected impervious areas \\
& Frontal area density & Building material fraction \\
\hline
\end{tabular}

facets, elements, streets and blocks, and neighborhoods (Oke et al. 2017). Facets describe flat and uniform features that are distinguished by their slope and aspect and radiative and thermal properties. Elements are the combination of facets that create 3D features like building typologies. Streets and blocks represent the organization of elements to form distinct geometries, and neighborhoods describe a common and repeated amalgam of facets, elements, and streets and blocks over an area. To cope with this complexity, WUDAPT information is organized by level of detail $(L)$, and data at each level are gathered using distinct methodologies and techniques.

The lowest level of detail (L0) maps cities and their surrounding natural landscape into local climate zone (LCZ) types (Stewart and Oke 2012). L1 data use the LCZ maps to provide a sampling context for acquiring and managing information at finer scales. L2 data are complete information on all urban elements (e.g., building footprints, envelope fabrics, and heights) that may exist for some urban areas, albeit coverage is limited to a few cities; for example, NUDAPT data for Houston include detailed information (dimensions

TABLE 2. Some of the UCP values associated with LCZ types from Stewart and Oke (2012). Columns represent the percentage of impervious $\left(\lambda_{1}\right)$, built $\left(\lambda_{b}\right)$, and vegetated $\left(\lambda_{v}\right)$ land cover and mean height of building elements $(z)$, sky view factor $\left(\lambda_{s}\right.$; see Fig. Ia), albedo $(a)$, and anthropogenic heat flux $\left(Q_{F}\right)$.

\begin{tabular}{|lccccccc|}
\hline $\mathbf{L C Z}$ & $\lambda_{I}$ & $\lambda_{b}$ & $\lambda_{v}$ & $\mathbf{z}(\mathbf{m})$ & $\lambda_{s}$ & $\boldsymbol{a}$ & $\mathbf{Q}_{F}\left(\mathbf{W} \mathbf{m}^{-2}\right)$ \\
\hline I. Compact high rise & $40-60$ & $40-60$ & $<10$ & $>25$ & $0.2-0.4$ & $0.10-0.20$ & $50-300$ \\
\hline 2. Compact midrise & $40-70$ & $30-50$ & $<20$ & $10-25$ & $0.3-0.6$ & $0.10-0.20$ & $<75$ \\
\hline 3. Compact low rise & $40-70$ & $20-50$ & $<30$ & $3-10$ & $0.2-0.6$ & $0.10-0.20$ & $<75$ \\
\hline 4. Open high rise & $20-40$ & $30-40$ & $30-40$ & $>25$ & $0.5-0.7$ & $0.12-0.25$ & $<50$ \\
\hline 5. Open midrise & $20-40$ & $30-50$ & $20-40$ & $10-25$ & $0.5-0.8$ & $0.12-0.25$ & $<25$ \\
\hline 6. Open low rise & $20-40$ & $20-50$ & $30-60$ & $3-10$ & $0.6-0.9$ & $0.12-0.25$ & $<25$ \\
\hline 7. Lightweight low rise & $60-90$ & $<20$ & $<30$ & $2-4$ & $0.2-0.5$ & $0.15-0.35$ & $<35$ \\
\hline 8. Large low rise & $30-50$ & $40-50$ & $<20$ & $3-10$ & $>0.7$ & $0.15-0.25$ & $<50$ \\
\hline 9. Sparsely built & $10-20$ & $<20$ & $60-80$ & $3-10$ & $>0.8$ & $0.12-0.25$ & $<10$ \\
\hline I0. Heavy industry & $20-30$ & $20-40$ & $40-50$ & $5-15$ & $0.6-0.9$ & $0.12-0.20$ & $>300$ \\
\hline A. Dense trees & $<10$ & $<10$ & $>90$ & $3-30$ & $<0.4$ & $0.10-0.20$ \\
\hline B. Scattered trees & $<10$ & $<10$ & $>90$ & $3-15$ & $0.5-0.8$ & $0.15-0.25$ \\
\hline C. Bush, scrub & $<10$ & $<10$ & $>90$ & $<2$ & $0.7-0.9$ & $0.15-0.30$ \\
\hline D. Low plants & $<10$ & $<10$ & $>90$ & $<1$ & $0.2-0.4$ & $0.15-0.25$ & 0 \\
\hline E. Bare rock or paved & $<10$ & $>90$ & $<10$ & $<0.25$ & $>0.9$ & $0.15-0.30$ & 0 \\
\hline F. Bare soil or sand & $<10$ & $<10$ & $>90$ & $<0.25$ & $>0.9$ & $0.20-0.35$ & 0 \\
\hline G. Water & $<10$ & $<10$ & $>90$ & - & $>0.9$ & $0.02-0.10$ & 0 \\
\hline
\end{tabular}


and construction materials) for every building in the city center (Ching et al. 2009), and Applied Modeling and Urban Planning Laws: Urban Climate and Energy (MApUCE) data comprise a complete inventory of buildings in France (Masson et al. 2015).

The protocols for deriving and using L0 data are now well developed (Bechtel and Daneke 2012; Bechtel et al. 2015, 2017a,b), and there are currently over 80 cities globally for which data are available. The methods for acquiring, managing, and using higher-level data within the WUDAPT framework is being developed (see "Current status and next steps" section), but WUDAPT is already recognized as a framework for urban climate research to integrate more complex physical processes in urban canopy models (e.g., Wouters et al. 2016).

Level 0 data. The Stewart and Oke (2012) LCZ typology was designed primarily to describe the features that impact the near-surface local thermal environment, specifically the roles of land cover and anthropogenic heat on the magnitude of the observed UHI (e.g., Alexander and Mills 2014). Its outstanding merit is that it is designed as a culturally neutral description of urban landscapes and, critically, each of the 17 basic types (10 of which are urban) is associated with typical value ranges for a set of key urban canopy parameters (Table 2). L0 data are derived using Landsat data, image software, and the knowledge of urban experts (see Bechtel and Daneke 2012; Bechtel et al. 2015, 2017a). The urban experts are critical to the process, as they create the training areas (TAs) that identify the parts of the city under study that exemplify each LCZ type. This information is used to classify Landsat scenes into LCZ maps using a random forest (RF) classifier implemented in the System for Automated Geoscientific Analyses (SAGA) software (Conrad et al. 2015).

The quality of the L0 data relies on the skill of the experts that create the TAs, and considerable effort has been placed on training experts and on independent assessment of the TA data. The current quality control scheme emphasizes the statistical reliability of a city database by randomly dividing
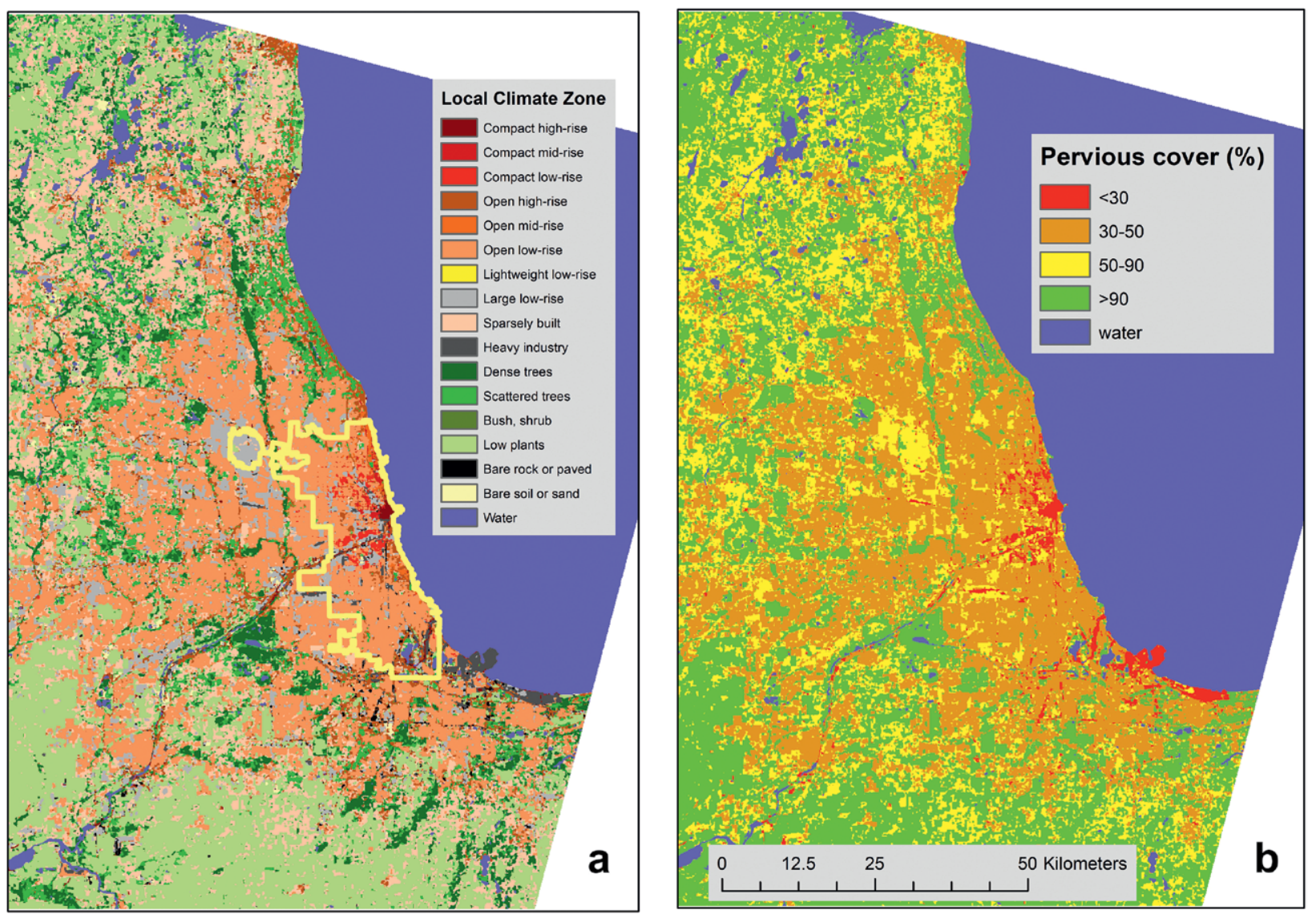

FIg. 2. WUDAPT LO data for Chicago and derived urban canopy parameters: (a) the distribution and legend of LCZs derived from Landsat images using the WUDAPT protocol and (b) the area fraction of pervious surface cover derived from Table 2 . 

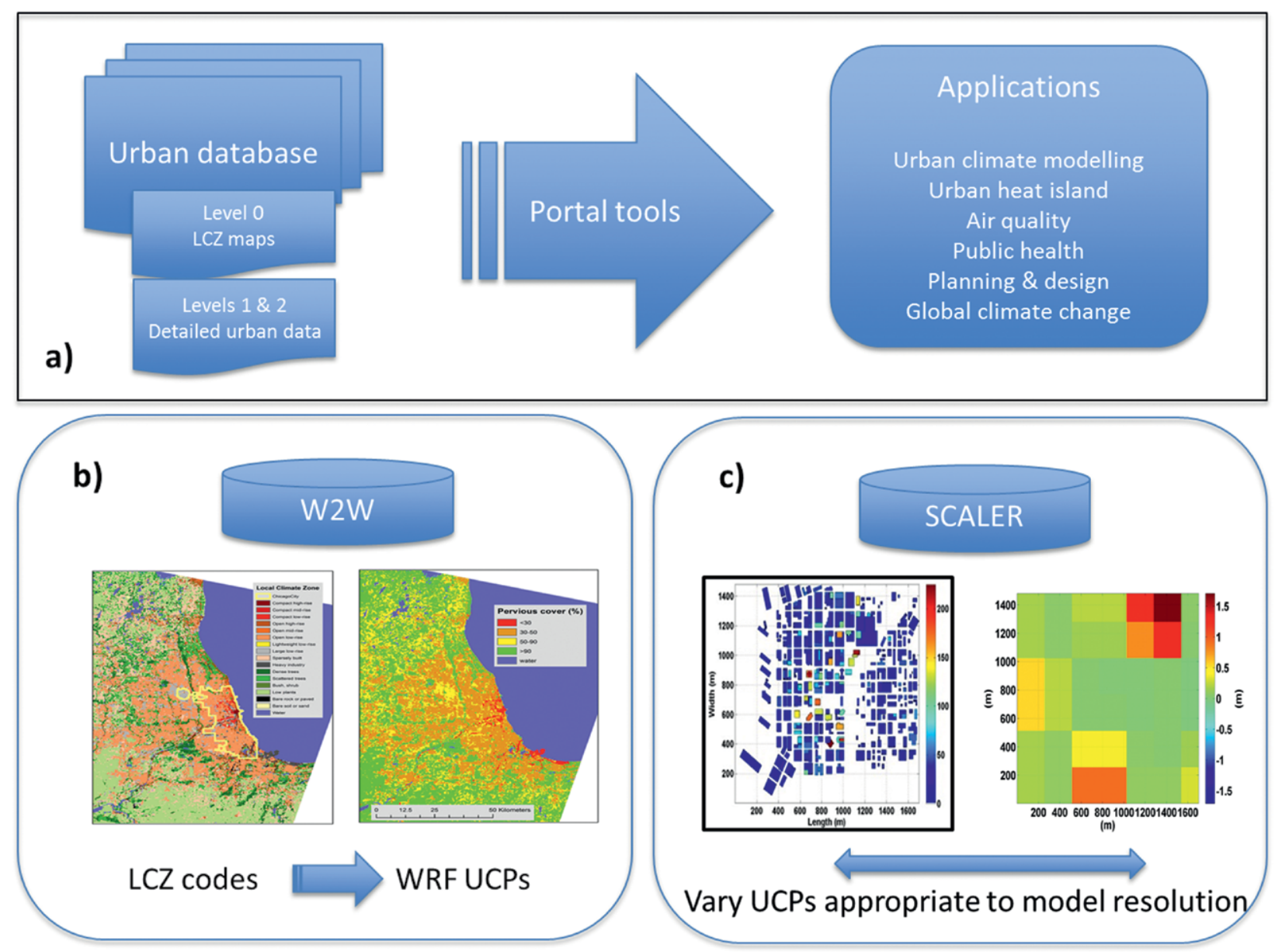

FIG. 3. (a) The schematic of the WUDAPT project and its current portal tools: (b) W2W tool is designed to integrate WUDAPT table lookup UCP data for each LCZ to facilitate its use in the WRF Model and (c) SCALER, a tool that permits the extraction of WUDAPT-type data to user-specified grid resolution.

the TAs into a set for training and a set for evaluation purposes. With each iteration, an LCZ map is generated for a given TA set, and the resulting LCZs are compared with the evaluation set; overall accuracy $(\mathrm{OA})$ is measured as the percent of LCZ values that are predicted correctly. Repeatedly sampling (i.e., bootstrapping) from the TAs allows us to measure the robustness of the LCZ map, that is, the consistency of the LCZ map when using different sets of training areas. A WUDAPT committee that oversees the quality of the L0 data examines the final LCZ map to ensure that it provides an accurate depiction of the urban landscape. There are currently more than 80 cities that are in the WUDAPT database; the reader should refer to the website (www.wudapt.org) for updates.

Each LCZ map encodes UCP values that can be used in models [a subset of the list of parameters is shown in Table 2 and in Stewart and Oke (2012) and its supplemental material]; these UCPs are used in models and climate analyses. As an example, Fig. 2 shows the LCZ map for the Chicago, Illinois, area alongside a map of the pervious fraction that has been generated from a lookup table (Table 2); note that LCZ types are associated with ranges of UCP values. Establishing the veracity of the derived data is not straightforward, as it requires independently derived information that is comparable in scope and spatial resolution. Experiments on a few cities have shown good agreement, but these tests are, to this point, limited to plan area fractions in western cities (Mills et al. 2015, 2017a,b).

The WUDAPT portal. The portal is designed to support climate research that requires urban information (Ching et al. 2015). Critically, it should allow users to extract relevant data at an appropriate spatial scale for modeling purposes. Currently, WUDAPT provides tools that can utilize the L0 data (Fig. 3a), but other tools that require L1/L2 data are being designed; here we describe two portal tools, WUDAPT to WRF (W2W; Fig. 3b) and SCALER (Fig. 3c). 


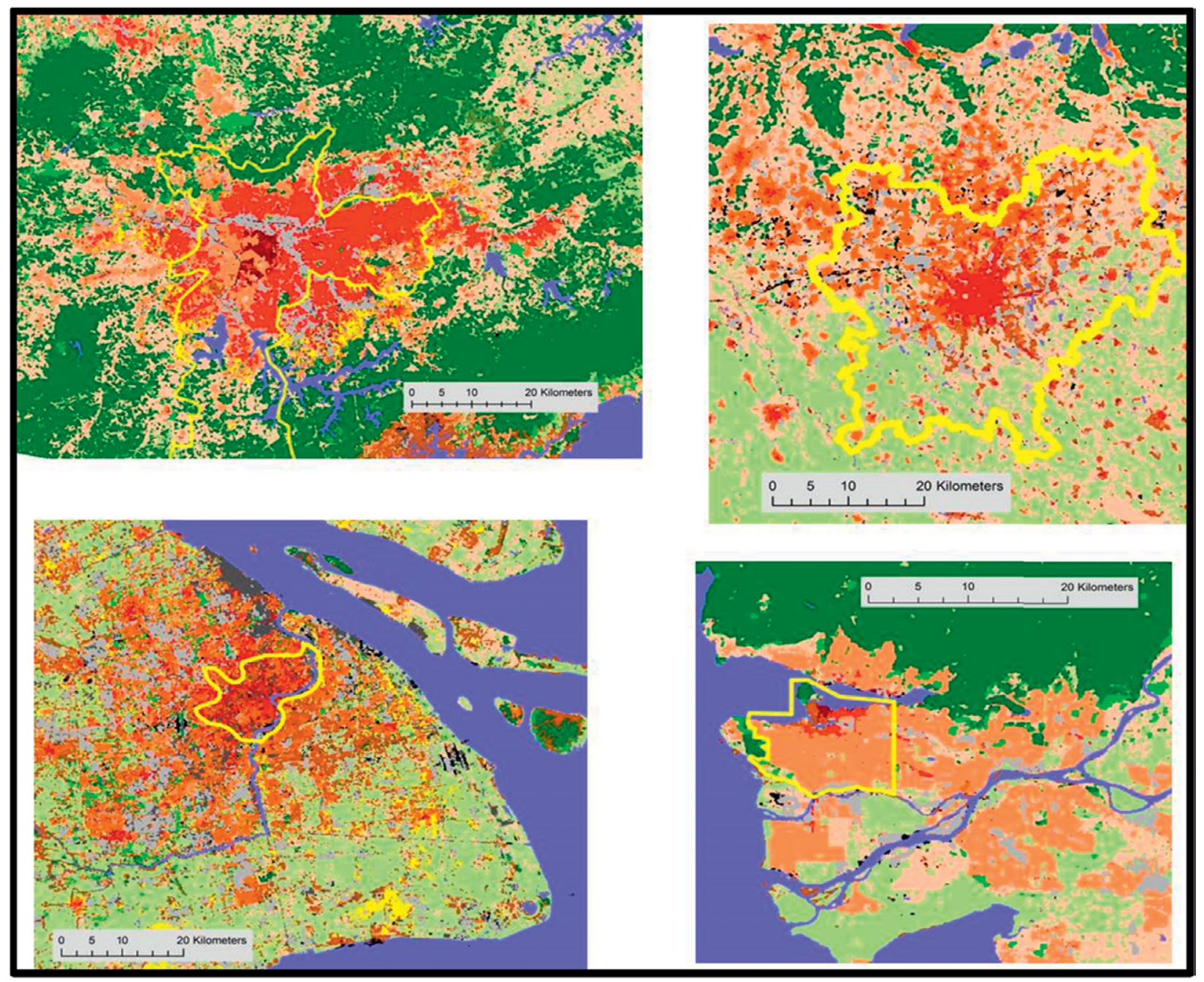

Fıg. 4. A comparison of WUDAPT LO maps for selected cities: (top left) São Paulo, Brazil; (top right) Milan, Italy; (bottom left) Shanghai, China; and (bottom right) Vancouver, Canada. In each case the administrative boundaries of the city or municipality are shown. The LCZ legend is as in Fig. 2 a.

The W2W tool was developed to convert L0 data into a gridded format suitable for urban schemes used in the WRF Model; these include the single-layer urban canopy model (Kusaka et al. 2001; Kusaka and Kimura 2004) and the Building Effect Parameterization and Building Energy Model (BEP-BEM) scheme (Martilli et al. 2002; Salamanca et al. 2010). Converting the LCZ parameter information into UCPs suitable for these schemes requires some modification. For example, BEP-BEM requires information on street width, building footprints, and pervious surface cover that can be estimated from the LCZ data by selecting the midpoint values of the available ranges (Table 2). It also requires information on the distribution of building heights within a grid cell, for which there is not a unique solution. The simplest option, which is in use, is to choose three heights, one close to the midpoint value (considering the constraint that it must be a multiple of $5 \mathrm{~m}$ ) with a probability of $50 \%$ and two other heights above and below that, but within the given range and a multiple of $5 \mathrm{~m}$, with a probability of $25 \%$. The important point, however, is that $\mathrm{W} 2 \mathrm{~W}$ provides a standardized means for incorporating UCPs into urbanized WRF and permits greater comparability between studies (Brousse et al. 2016); some examples are shown in the next section. Current and subsequent updates of W2W documentation (Martilli et al. 2016) are provided as a link under "Resources" on the WUDAPT website (www.wudapt.org).

SCALER generates appropriately scaled model inputs to various modeling systems (Fig. 3c). This tool uses the principle of the multiple resolution analysis (MRA) to manage the multiscale grid requirements of users (Mouzourides et al. 2013, 2014). Its unique feature is its ability to retain subgrid data on the input parameters as the selected model grid 


\begin{tabular}{|c|c|c|c|c|c|c|c|c|c|c|}
\hline \multirow{2}{*}{$\begin{array}{l}\text { LCZ type } \\
\text { Compact high rise }\end{array}$} & \multicolumn{2}{|c|}{ Chicago } & \multicolumn{2}{|c|}{ Milan } & \multicolumn{2}{|c|}{ Shanghai } & \multicolumn{2}{|c|}{ São Paulo } & \multicolumn{2}{|c|}{ Vancouver } \\
\hline & 0.20 & 2.08 & 0.00 & 0.00 & 0.25 & 4.47 & 0.51 & 2.81 & 0.15 & 1.36 \\
\hline Compact midrise & 0.10 & 2.39 & 2.11 & 6.32 & 1.35 & 21.56 & 0.10 & 0.31 & 0.00 & 0.06 \\
\hline Compact low rise & 0.19 & 4.00 & 0.10 & 0.25 & 0.77 & 6.23 & 6.39 & 26.04 & 0.47 & 3.93 \\
\hline Open high rise & 3.31 & 8.39 & 1.98 & 5.47 & 8.66 & $15.5 \mid$ & 1.85 & 1.16 & 1.00 & 4.97 \\
\hline Open midrise & 0.14 & 2.43 & 7.84 & 16.13 & 6.31 & 15.91 & 1.01 & 1.70 & 0.04 & 0.03 \\
\hline Open low rise & 14.54 & 53.92 & 3.57 & 0.38 & 2.44 & 3.20 & 8.03 & 15.57 & 19.97 & 60.18 \\
\hline Lightweight low rise & 0.00 & 0.00 & 0.00 & 0.00 & 4.35 & 2.06 & 1.45 & 3.45 & 0.00 & 0.00 \\
\hline \begin{tabular}{|l|} 
Large low rise \\
\end{tabular} & 3.58 & 13.15 & 4.75 & 10.70 & 8.65 & 5.18 & 3.63 & 9.83 & 3.86 & 4.82 \\
\hline Sparsely built & 13.01 & 2.78 & 29.69 & 33.47 & 6.16 & 0.05 & 22.12 & 12.54 & 11.30 & 3.44 \\
\hline Heavy industry & 0.53 & 3.22 & 0.00 & 0.00 & 3.92 & 17.10 & 0.66 & 0.89 & 0.00 & 0.00 \\
\hline Dense trees & 3.92 & 0.93 & 20.03 & 0.42 & 1.19 & 0.38 & 39.05 & 18.11 & 25.59 & 1.92 \\
\hline Scattered trees & 6.85 & 2.28 & 0.47 & 0.51 & 1.63 & 0.31 & 3.07 & 1.62 & 2.02 & 1.73 \\
\hline Bush, scrub & 0.00 & 0.00 & 0.00 & 0.00 & 0.00 & 0.00 & 1.51 & 0.50 & 0.00 & 0.00 \\
\hline Low plants & 20.55 & 1.68 & 25.34 & 23.58 & 26.31 & 0.23 & 5.61 & 1.27 & 14.36 & 2.79 \\
\hline Bare rock or paved & 0.26 & 0.80 & 1.10 & 2.16 & 0.76 & 1.43 & 0.07 & 0.05 & 0.24 & 0.22 \\
\hline Bare soil or sand & 0.54 & 0.40 & 0.00 & 0.00 & 0.00 & 0.00 & 0.44 & 0.19 & 0.00 & 0.00 \\
\hline Water & 32.26 & 1.55 & 3.02 & 0.60 & 27.24 & 6.37 & 4.49 & 3.97 & 21.01 & 14.56 \\
\hline Area $\left(\mathrm{km}^{2}\right)$ & 15,584 & 597 & 6,236 & 1,344 & 8,887 & 197 & 9,278 & 1,410 & 2,277 & 136 \\
\hline
\end{tabular}

scale is increased. This allows the impact of subgrid UCP variability on resulting model outputs to be examined and enables a clearer understanding of the role and impact of such parameters on the behavior of a complex urban system. It has already been used to explore the scale-dependent links between energy demand and urban weather (Neophytou et al. 2015; Mouzourides et al. 2017).

INITIAL ANALYSES AND SAMPLE APPLICATIONS. The innovation of the LCZ scheme explained earlier is that it provides a common platform for comparing cities in terms of urban form and, to a lesser extent, urban function (Stewart and Oke 2012; Gál et al. 2015). Figure 4 shows a sample of LCZ (and their corresponding urban canopy parameters) maps for a variety of cities, revealing their unique and distinct spatial patterns of distribution. Thus, each urban area will have its own unique spatial distribution of urban canopy parameters and, therefore, mesoscale modeling outcomes. The areal coverage for each LCZ type present is shown in Table 3 for both the region of interest (ROI) and official urban administrative area (shown in Fig. 4). Generally, relatively small proportions are occupied by compact urban neighborhoods-the exception is Shanghai, but it has the smallest area within the official city boundary. Chicago and Vancouver are distinguished by the extent of the open low rise (LCZ 6) and the extent of nearby water. Low plant (LCZ D) characterizes the natural cover outside most cities, but in the case of São Paulo it is dense trees (LCZ A).

These different LCZ geographies should give rise to different urban climate effects. To illustrate, Fig. 5 shows the LCZ maps for São Paulo and Mumbai (India) alongside Moderate Resolution Imaging Spectroradiometer (MODIS)-derived mean annual surface temperature (MAST), which was computed from a 12-yr time series of MODIS land surface temperature acquired at 2230 local time and is a cloud-free, robust, and representative measure of long-term land surface temperature (Bechtel 2015). The spatial pattern and magnitude of temperature clearly corresponds with the underlying LCZ surface cover.

In the following examples, the potential for a consistent climate-based landscape classification scheme is illustrated for the ubiquitous urban effect on temperature (i.e., the UHI). But, of course, there are many other applications, such as air quality modeling, the creation of urban climatic maps to aid climate sensitive urban design (Ren et al. 2017), and improving the representation of cities in global climate models 

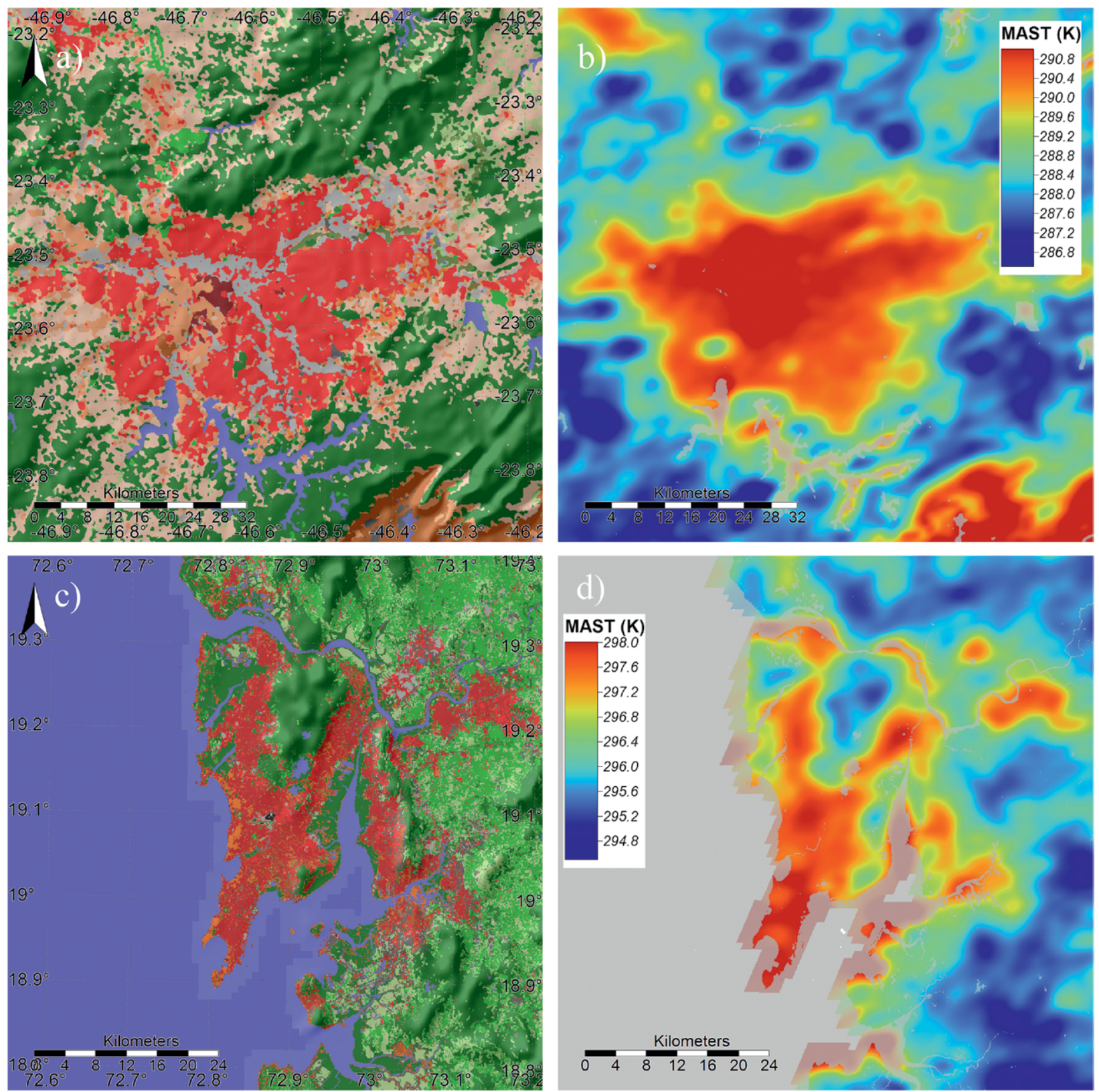

Fıg. 5. WUDAPT LO maps and MAST at 2230 LT in kelvin for (a),(b) São Paulo, Brazil, and (c),(d) Mumbai, India. The underlying topography shown in (a) and (c) is based on the Shuttle Radar Topography Mission. The LCZ legend is as in Fig. 2 a.

(Feddema et al. 2015). The UHI, which includes the urban effect on surface, subsurface, and air temperatures, is one of the often-studied aspects of the urban climate. The surface $\mathrm{UHI}\left(\mathrm{UHI}_{\text {surf }}\right.$ ) as observed from the vantage of a satellite (e.g., Fig. 5) and the nearsurface (canopy level) UHI ( $\mathrm{UHI}_{\mathrm{UCL}}$ ) are often used as measures of urban impact on building energy use and heat stress (Oke et al. 2017).

The cause of $\mathrm{UHI}_{\text {surf }}$ is primarily linked to the properties of construction materials (their radiative and thermal properties) and their dryness state-as consequence, urban surfaces (when viewed from above) generally tend to be warmer by day and night (Oke et al. 2017). Therefore, the magnitude of the $\mathrm{UHI}_{\text {surf }}$ depends on both the character of the urban surface and the nature of the surrounding nonurban landscape (vegetative cover, moisture status, season, etc.). The $\mathrm{UHI}_{\text {surf }}$ can be simulated by solving the surface energy balance, which accounts for the exchanges of radiation and sensible and latent heat fluxes between the surface and the overlying atmosphere. The SUEWS model can derive these energy balance terms 


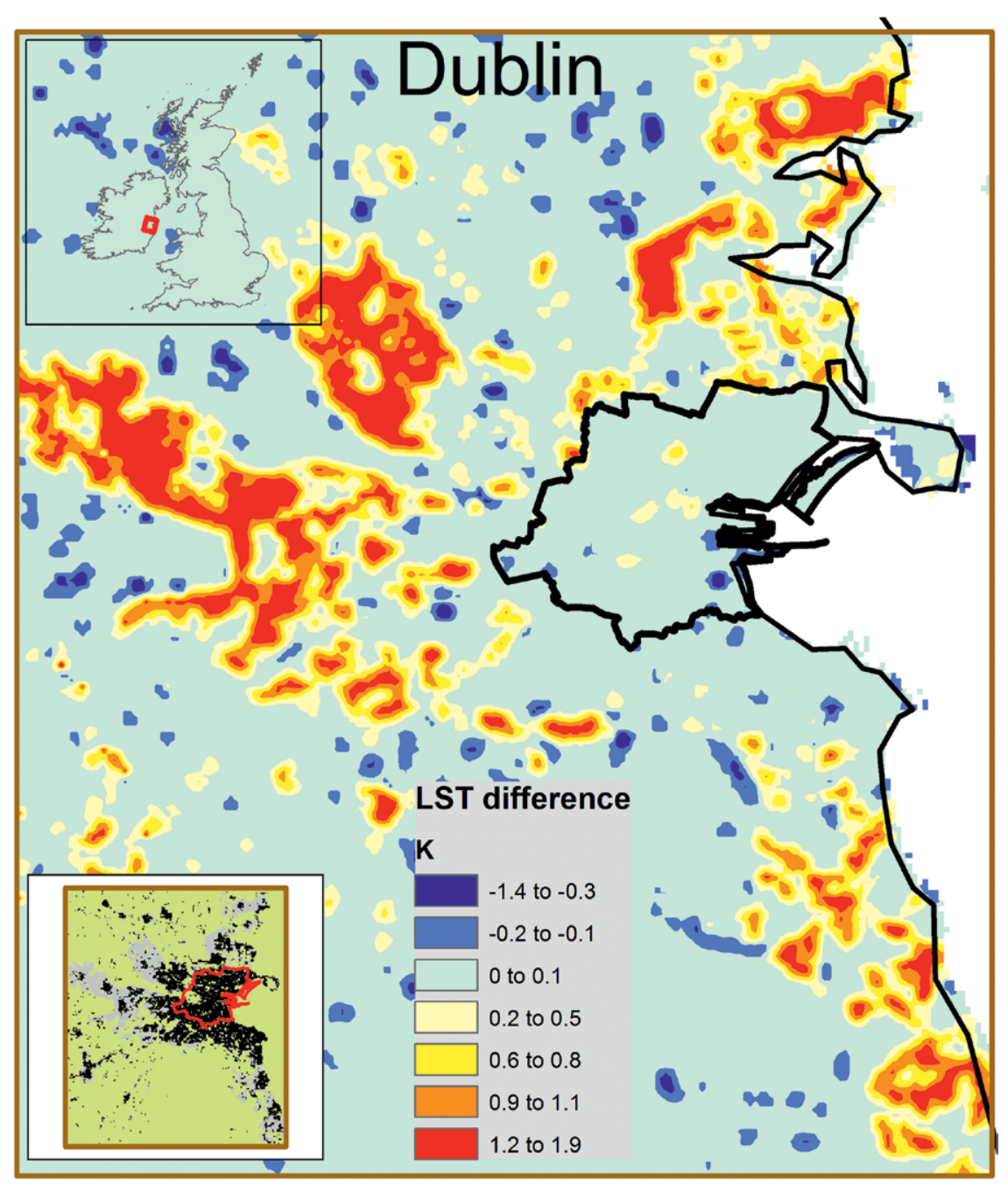

FIG. 6. The impact of urban growth on mean surface temperature for Dublin, Ireland (top inset map). The SUEWS model was run using parameter data derived from WUDAPT LO data. Simulations were carried out for current (2006) and projected (2026) urban cover (bottom inset map) using typical Jun weather and the map shows the difference in their surface temperatures $(K)$. growth and urban growth made in 2006. Land cover in 2006 and 2026 was converted to LCZ types, which were then used to derive parameter values for SUEWS and simulations based on current climate. The results show a more extensive $\mathrm{UHI}_{\text {surf }}$ that reflects the replacement of natural surface cover by urbanization. On the other hand, an alternative projection based on increased building density rather than expanding the urban footprint does not change the $\mathrm{UHI}_{\text {surf }}$ appreciably. This experiment shows the potential value of WUDAPT data in an applied planning context.

The urban canopy layer UHI $\left(\mathrm{UHI}_{\mathrm{UCL}}\right)$ describes the impact of cities on the near-surface $(\sim 2 \mathrm{~m})$ air temperature; typically, the near-surface air in cities is warmer than that in the surrounding natural area and is strongest at night under clear skies and calm conditions in densely built parts of the city. Although it is linked to the $\mathrm{UHI}_{\text {surf }}$, it has its own distinct genesis processes linked mostly to using commonly measured meteorological variables and information about land cover. For a given area it requires the fractional areas occupied by paving, buildings, coniferous trees/shrubs, deciduous trees/ shrubs, irrigated grass, nonirrigated grass, and water. SUEWS has been evaluated across a range of urban landscapes and is ideally suited to simulate surfaceair exchanges during weather dominated by clear and calm conditions that are conducive to UHI formation (Järvi et al. 2011).

Alexander et al. (2016) used SUEWS to examine the climate impacts of different urban development paths, using the example of Dublin, Ireland. Figure 6 shows the results of a simulation experiment, comparing the average surface temperature for June for Dublin in 2026, based on projections of population the geometry and underlying material composition of the UCL that regulates the nighttime loss on longwave radiation (Oke et al. 2017) and the thermal character of the built fabric, which stores daytime heat and anthropogenic additions of heat. Atmospheric models that simulate the $\mathrm{UHI}_{\mathrm{UCL}}$ require detailed information on the character of the urban canopy. The most sophisticated models will nest the microscale details of the urban canopy layer within larger-scale mesoscale processes that regulate the background climate.

Figure 7 shows the results of a study on the Madrid, Spain, $\mathrm{UHI}_{\mathrm{UCL}}$ using WRF with the BEP-BEM scheme. The modeling setup consisted of five nested domains, with Madrid located in the inner domain of $7,200 \mathrm{~km}^{2}$ (shown in the inset at the top of the figure) composed of $240 \times 270$ cells at a resolution of $333 \mathrm{~m}$. 
The W2W tool generated the UCPs corresponding to the L0 maps that were used for the urban cells in the inner domain. Figure 7 shows the simulated surface air temperature under ideal weather conditions for $\mathrm{UHI}_{\mathrm{UCL}}$ formation, which shows the correspondence between the urban footprint and the magnitude of the heat island. The model output using WUDAPT data was compared with output derived using data in the European Environment Agency's Urban Atlas (www .eea.europa.eu/data-and -maps/explore-interactive -maps/urban-atlas-for -europe), which has limited information on land cover within municipal boundaries. Observations made at a weather station network in the city provided an independent assessment of model performance. The results showed that performance of the model using L0 corresponding UCPs improved model performance by $\sim 10 \%$ based on rmse and mean bias indicators. Given the relative ease with which LCZ maps can be generated, the results show the potential to greatly improve urban modeling capacity, particularly where no other land-cover data are available (Brousse et al. 2016).

Heat waves are a leading cause of weather-related fatalities globally, and there is evidence that the UHI can act synergistically with expected global climate change to enhance the risk to public health in cities (Li and Bou-Zeid 2013). In Fig. 8 the results of a study of heat stress in New Delhi, India, are presented. In this study a baseline event was simulated based on a heat wave event (22-27 May 2015) that advected very hot and dry air into the city; during this period the maximum and minimum temperatures in New Delhi reached $46^{\circ}$ and $32^{\circ} \mathrm{C}$, respectively. To examine the impact of urban growth on the intensity and extent of the associated heat stress, L0 data were generated for the modeling domain at two time periods (1977 and 2015) and the W2W tool was used to generate appropriate UCP values for WRF (Niyogi et al. 2017). Simulations were performed using the synoptic forcing conditions that prevailed during the 2015 event and the National Oceanic and Atmospheric Administration (NOAA) heat index (HI) was calculated. HI represents the heat stress associated with high temperature and relative humidity as an "apparent" temperature; in Fig. 8 the difference between the HI values for 2015 and 1977 is presented. This difference map shows that urban development has increased both the spatial extent and the magnitude of the heat stress. This example illustrates the value of improved urban land-cover descriptions for extreme weather modeling predictions. 


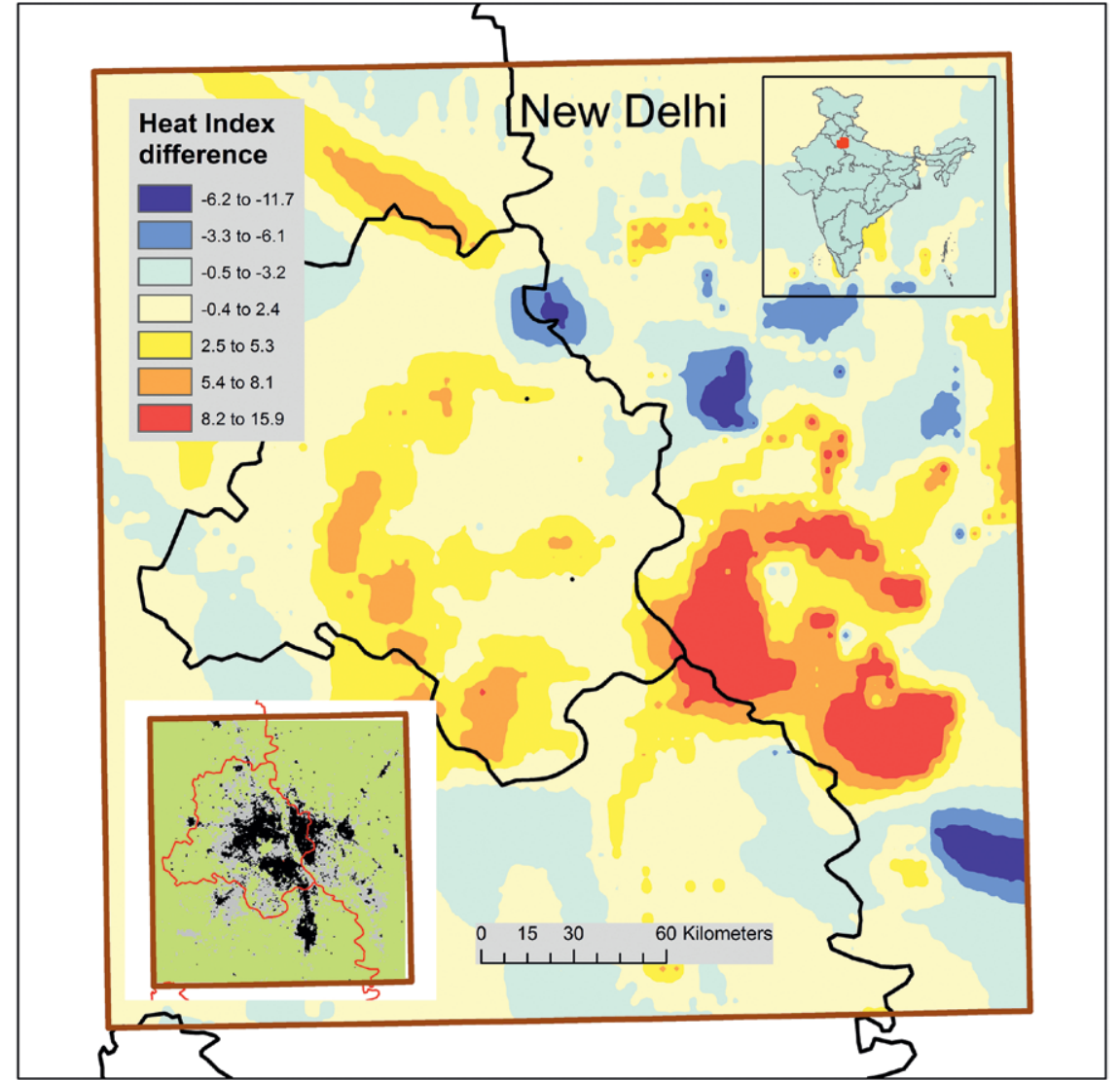

FIG. 8. The simulated impact of urban development on heat stress over New Delhi, India (top inset map). The WRF Model was run using WUDAPT LO data for 1977 and 2015, based on weather conditions for 25 May 2015. The growth of the city over this period is shown in the bottom inset map. The WRF simulation was used to calculate the NOAA HI, expressed as apparent temperature in Fahrenheit; the figure depicts the difference: $\mathrm{HI}_{2015}-\mathbf{H I}_{1977^{\circ}}$
UCP values from Zhang et al. (2010a,b) and based on WUDAPT L0 data (Fig. 9b). The observable differences are the result of the simulated wind fields that reflect advanced urban physics parameterizations in WRF that can take advantage of the quality of urban data provided. Also, preliminary work on modeling air quality over São Paulo (Dirce et al. 2018, manuscript submitted to Urban Climate) confirms that significant spatial and temporal variability in the complex 3D flows and mixed layer height variations across the city are evident when more precise urban data (i.e., L0 data) are provided.

While WUDAPT continues to acquire L0 data for additional cities, the longterm strategy recognizes the need for a multidimensional approach to data gathering and processing with an emphasis on gathering additional socioeconomic
CURRENT STATUS AND NEXT STEPS. As it stands, researchers can use open-source tools and Landsat data to generate L0 data quickly, which overcomes a major obstacle to model application where there are no data currently. In addition to the projects presented above, which focused on the urban heat island, there is evidence that the dynamics and chemistry simulated in urban models are sensitive to the description of the underlying city surface. Figure 9 shows preliminary results from a study of air quality in Guangzhou, China, using the single-layer urban canopy model coupled to Noah in the WRF Model coupled with chemistry (WRF-Chem; Grell et al. 2005; Kusaka et al. 2001). The figure depicts the time-height cross section of simulated $\mathrm{PM}_{2.5}$ (particles with size $\leq 2.5 \mu \mathrm{m}$ ) distribution in the upper boundary layer for a fair weather period (15-17 October 2014) that corresponded with a pollution episode. The cross sections show two simulations based on a generic "urban" category (Fig. 9a) using and surface variables. There are a number of activities underway to improve WUDAPT and its products and extend modeling application capabilities.

LO data quality and UCP precision. Much of the effort in designing the protocol for L0 data has focused on ensuring the quality of the data. For example, experiments have demonstrated that using a contextual classifier that takes into account information in neighboring pixels during the LCZ mapping process can significantly improve the quality of the map (Verdonck et al. 2017). However, the quality of the TAs remains the foundation of the protocol for generating the LCZ maps. At a minimum, L0 data should be reproducible by independent evaluators to achieve a high level of self-consistency, but experience has shown that there is considerable variation among the urban experts in their creation of TAs. As part of the Human Influence Experiment (HUMINEX) initiative, Bechtel et al. (2017b) investigated 94 


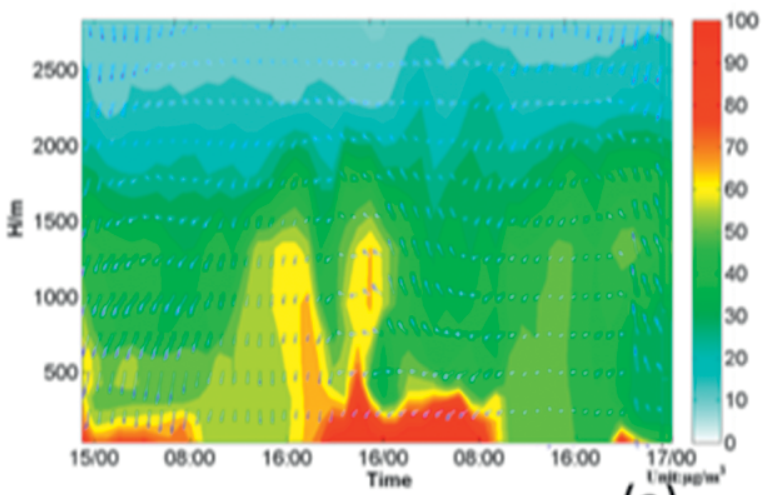

(a)

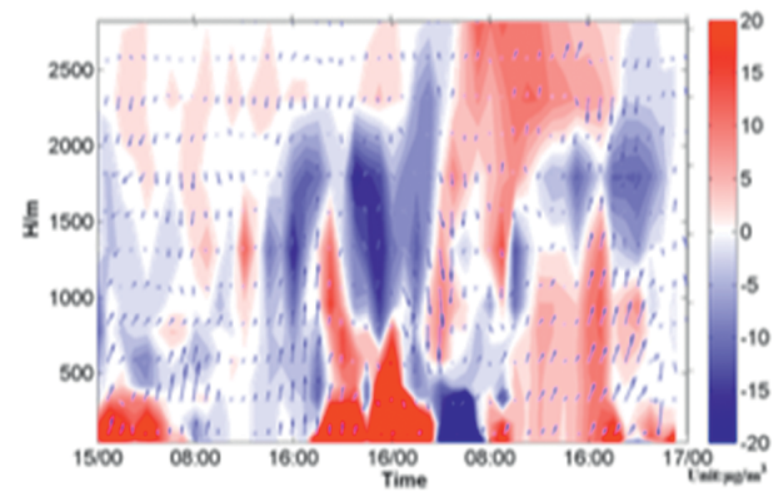

(c)

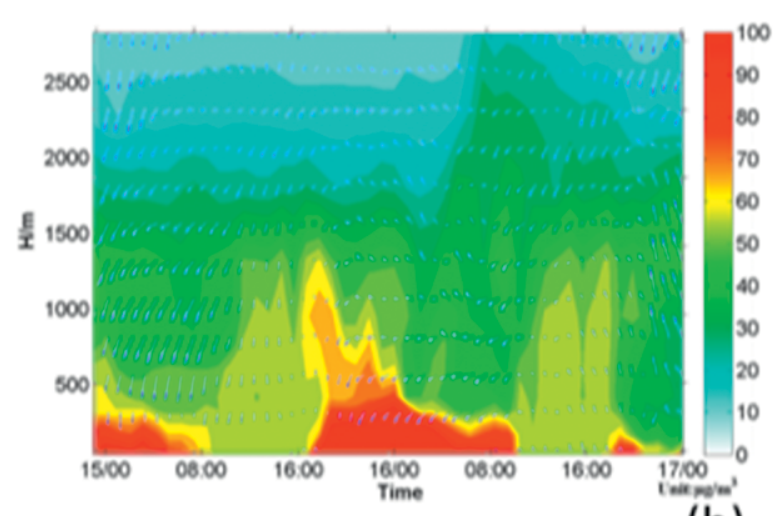

(b)

\begin{abstract}
FIG. 9. Example of air quality $\left(\mathrm{PM}_{2.5}\right)$ model sensitivity study using WRF-Chem for (a) standard default WRF physics (for urban category as high-intensity residential) vs (b) urban canopy parameterization modeling based on WUDAPT LO data. (c) The arrows refer to the difference of vertical velocity simulations.
\end{abstract}

crowdsourced training datasets for 10 different cities. The results indicate that while LCZ maps generated by TAs from one individual may be of poor quality, increasing the number of training data revisions and combining multiple training sets increases the quality of L0 data considerably.

In related work, cross evaluations are being undertaken with comparable urban land-cover information where it is available, such as the impermeable surface cover recorded in Europe's Urban Atlas and the built cover available in the Global Human Settlement Layer (Pesaresi et al. 2013). This work also has the potential to provide more precise UCP values for LCZ types, which are currently based on the information presented in Table 2. The objective of this endeavor is to generate guidance for assigning the most probable values of UCPs by LCZs to each grid in the modeling domain.

Actions to acquire higher-level data. Developing richer urban databases, in terms of both spatial detail and adding other relevant variables (such as building and vegetation characteristics), is a goal for the next phase of WUDAPT (Ching et al. 2017a). The information on buildings will be gathered using an approach similar to that for gathering L0 data, that

is, to develop and employ an international building typology with associated physical and functional properties. Data acquisition will rely on crowdsourcing techniques such as smartphone and web-based tools and will utilize the WUDAPT community (See et al. 2015). The paradigm for this initiative is based on the MApUCE project, which employs France's building database to extract detailed UCPs related to building dimensions, construction materials, and occupation patterns (Masson et al. 2015, 2017). Members of the Passive Low Energy Architecture (PLEA) community are helping to create the WUDAPT building typology (Ching et al. 2017b). The existing L0 data (i.e., LCZ maps) will be used to provide a context for the data gathered and manage sampling across the urban landscape. The quality evaluation will require other independently derived data such as those available in some national censuses. Where possible, advanced satellite data and processing algorithms can provide high-definition data on building form (Wang and Dai 2015); the feasibility of this has already been demonstrated by Xu et al. (2017a,b). These sources could also provide UCPs, such as building volume density, ground coverage ratio, frontal area density, open spaces, and greenery coverage ratio. 
Portal tools. WUDAPT tools are being developed to make maximum use of these data as they emerge. Priority capabilities under consideration include tools that 1) link the database to the wide variety of urban climate models in stand-alone configurations (e.g., Grimmond et al. 2010) or as components to largerscale models such as WRF, 2) allow weather data gathered at World Meteorological Organization (WMO) standard stations outside cities to be transferred to urban locations (e.g., Erell and Williamson 2006), 3) combine with other available modeling software (e.g., Vanegas et al. 2012a,b) and land-cover data to create future urban growth scenarios, and 4) evaluate urban risks associated with current and future climate hazards, (e.g., Hanna et al. 2015).

Further enhancements may be possible through links enabled through WUDAPT (www.wudapt.org), given the rich datasets afforded by variety and types of remotely sensed datasets beyond the traditional and basic Landsat land-use-land-cover classifications. Inclusion of such information in WUDAPT would be as ancillary and auxiliary data for enhanced analyses (e.g., Comarazamy et al. 2013, 2015; Hulley et al. 2014; Imhoff et al. 2010; Luvall et al. 2015).

OUTLOOK. Urban issues are rapidly moving to the forefront of the challenges posed by climate changes across a hierarchy of scales. The WUDAPT project is developing a comprehensive global archive of urban data and associated tools that will be needed to address these challenges. The WMO is exploring the use of WUDAPT as a means toward addressing its new urban services mandates expressed in Resolution 68 (WMO 2015) and in development of the Guide for Integrated Urban Hydrometeorological, Climate and Environmental Services (Baklanov et al. 2018). In China, WUDAPT data have already been used for urban impact analyses studies of dynamic growth in the Pearl River delta (Ren et al. 2017) and in examining the impact of urbanization as part of China's "One Belt, One Road" plan. WUDAPT is participating with the Group on Earth Observations (GEO) WUDAPT in the Global Human Settlement Layer Project (Pesaresi et al. 2013) and the Human Planet Initiative, focusing on activities associated with global urban climate and mitigation planning actions.

WUDAPT is a successful grassroots effort, and continued community involvement is key to assuring success. Please consider engaging in and/or following the progress online (www.wudapt.org).

ACKNOWLEDGMENTS. We thank the International Association of Urban Climate (IAUC) for their encouragement and collaborations of IAUC experts to this initiative. The results to date are in large part due to the many urban experts from the IAUC who have unselfishly contributed their time as collaborators without compensation. We also thank Professors Tim Oke and Andreas Christen for contributing to Fig. 1. We gratefully acknowledge the support of the Argonne National Laboratory for supporting the first WUDAPT "Proof of Concept" workshop held in 2013 at UCD, Dublin, Ireland. We acknowledge IIASA for its continued support and encouragement to WUDAPT and for hosting the WUDAPT website. Several authors were partially supported by (i) the Vice-Chancellor's One-Off Discretionary Fund of the Chinese University of Hong Kong titled "World-wide Urban Data Bank on Physical Forms of Cities \& Impact Studies of Urban Forms on Human Comfort, Health and Environment Well-being" and by three General Research Fund Project Grants of the Hong Kong Research Grants Council: RGC-GRF 14611015, 14643816 and 16300715; (ii) the Cluster of Excellence CliSAP (EXC 177), University of Hamburg, funded through the German Science Foundation (DFG); (iii) US NSF CAREER AGS-0847472, NSF AGS-1522492 on extreme urban rainfall, ESSO-MoES, India (Grant/Project MM/SERP/CNRS/2013/INT-10/002) under Monsoon Mission; (iv) U.S. NSF Grant AGS-1243095 Collaborative Research: EaSM2 linking human and Earth Systems model to Assess Regional Impacts and Adaptation in Urban Systems and their Hinterlands; (v) NSF CBET 1250232 on STRONG Cities-Simulation Technologies for the Realization of Next Generation Cities; (vi) National Nature Science Foundation of China (41425020, 91644215); (vii) the Spanish government in the framework of the EXCLUR project (CGL2016-80154-R), (viii) the EU FP7-funded ERC grant CrowdLand (617754); and (ix) the REACT project funded by the STEREO-III program of the Belgian Science Policy (BELSPO, SR/00/337). Finally, we wish to thank all authors' institutions for their support to WUDAPT with in-kind resources and scientists time, most without external support.

\section{REFERENCES}

Alexander, P. J., and G. Mills, 2014: Local climate classification and Dublin's urban heat island. Atmosphere, 5, 755-774, https://doi.org/10.3390/atmos5040755.

_, B. Bechtel, W. T. L. Chow, R. Fealy, and G. Mills, 2016: Linking urban climate classification with an urban energy and water budget model: Multi-site and multi-seasonal evaluation. Urban Climate, 17, 196-215, https://doi.org/10.1016/j.uclim.2016.08.003. Baklanov, A., S. Grimmond, A. Mahura, and M. Athanassiadou, 2009: Meteorological and Air Quality Models for Urban Areas. Springer-Verlag Berlin 
Heidelberg, 184 pp., https://doi.org/10.1007/978-3 -642-00298-4.

-, and Coauthors, 2018: From urban meteorology, climate and environment research to urban integrated services. Urban Climate, 23, 330-341, https://doi. org/10.1016/j.uclim.2017.05.004.

Bechtel, B., 2015: A new global climatology of annual land surface temperature. Remote Sens., 7, 28502870, https://doi.org/10.3390/rs70302850.

- , and C. Daneke, 2012: Classification of local climate zones based on multiple Earth observation data. IEEE J. Sel. Top. Appl. Earth Obs. Remote Sens., 5, 11911202, https://doi.org/10.1109/JSTARS.2012.2189873.

—-, and Coauthors, 2015: Mapping local climate zones for a worldwide database of form and function of cities. ISPRS Int. J. Geo-Inf., 4, 199-219, https://doi .org/10.3390/ijgi4010199.

— - and Coauthors, 2017a: Beyond the urban mask: Local climate zones as a generic descriptor of urban areas-Potential and recent developments. Joint Urban Remote Sensing Event, Dubai, United Arab Emirates, IEEE, https://doi.org/10.1109/JURSE.2017.7924557.

_ - and Coauthors, 2017b: Quality of crowdsourced data on urban morphology-The Human Influence Experiment (HUMINEX). Urban Sci., 1, 15, https:// doi.org/10.3390/urbansci1020015.

Brousse, O., A. Martilli, M. Foley, G. Mills, and B. Bechtel, 2016: WUDAPT, an efficient land use producing data tool for mesoscale models: Integration of urban LCZ in WRF over Madrid. Urban Climate, 17, 116-134, https://doi.org/10.1016/j.uclim.2016.04.001.

Chen, F., and Coauthors, 2011: The integrated WRF/ urban modeling system: Development, evaluation, and applications to urban environmental problems. Int. J. Climatol., 31, 273-288, https://doi.org/10.1002 /joc.2158.

Ching, J., 2013: A perspective on urban canopy modeling for weather climate and air quality applications. Urban Climate, 3, 13-39, https://doi.org/10.1016/j .uclim.2013.02.001.

—- and Coauthors, 2009: National Urban Database and Access Portal Tool. Bull. Amer. Meteor. Soc., 90, 1157-1168, https://doi.org/10.1175/2009BAMS2675.1. — and Coauthors, 2015: The Portal component, strategic perspectives and review of tactical plans for full implementation of WUDAPT. Extended Abstracts, 9th Int. Conf. on Urban Climate/12th Symp. on the Urban Environment, Toulouse, France, Météo-France, 6 pp., www.meteo.fr/cic/meetings/2015/ICUC9 /LongAbstracts/gd2-5-4151235_a.pdf.

—, G. Mills, L. See, B. Bechtel, J. Feddema, I. Stewart, and A. Hanna, 2016: WUDAPT (World Urban Database and Access Portal Tools): An international collaborative project for climate relevant physical geography data for the world's cities. Fourth Symp. on Building a Weather-Ready Nation, New Orleans, LA, Amer. Meteor. Soc., TJ15.4, https://ams.confex .com/ams/96Annual/webprogram/Paper289993 .html.

_ , L. See, C. Ren, V. Masson, J. Hildalgo, X. Wang, G. Mills, and J. Feddema, 2017a: The WUDAPT framework to generating urban morphology, material composition and activity data for modeling. 13th Symp. of the Urban Environment, Seattle, WA, Amer. Meteor. Soc., 9.4, https://ams.confex.com /ams/97Annual/webprogram/Paper309318.html.

_ - and Coauthors, 2017b: Environmental modeling using WUDAPT for addressing climate change issues impacting urban areas. Design to Thrive: Proceedings of the PLEA 2017 Conference, L. Brotas, S. Roaf, and F. Nicol, Eds., Vol. II, PLEA, 1653-1660, https:// plea2017.net/.

Comarazamy, D. E., J. E. González, and J. C. Luvall, 2013: Climate impacts of land-cover and land-use changes in tropical islands under conditions of global climate change. J. Climate, 26, 1535-1550, https://doi .org/10.1175/JCLI-D-12-00087.1.

— — _ and — 2015: Quantification and mitigation of long-term impacts of urbanization and climate change in the tropical coastal city of San Juan, Puerto Rico. Int. J. Low Carbon Technol., 10, 87-97, https://doi.org/10.1093/ijlct/ctt059.

Conrad, O., and Coauthors, 2015: System for Automated Geoscientific Analyses (SAGA) v. 2.1.4. Geosci. Model Dev., 8, 1991-2007, https://doi.org/10.5194/gmd-8 $-1991-2015$

Crutzen, P. J., and E. F. Stoermer, 2000: The 'Anthropocene.' Global Change Newsletter, No. 41, International Geosphere-Biosphere Programme, Stockholm, Sweden, 17-18, www.igbp.net/download /18.316f18321323470177580001401/1376383088452 /NL41.pdf.

Dupont, S., T. Otte, and J. Ching, 2004: Simulation of meteorological fields within and above urban and rural canopies with a mesoscale model. Bound.Layer Meteor., 113, 111-158, https://doi.org/10.1023 /B:BOUN.0000037327.19159.ac.

Erell, E., and T. Williamson, 2006: Simulating air temperature in an urban street canyon in all weather conditions using measured data at a reference meteorological station. Int. J. Climatol., 26, 1671-1694, https://doi.org/10.1002/joc.1328.

Feddema, J., G. Mills, and J. Ching, 2015: Demonstrating the added value of WUDAPT for urban climate modelling. Extended Abstracts, 9th Int. Conf. on Urban Climate/12th Symp. on the Urban Environment, 
Toulouse, France, Météo-France, 4 pp., www .meteo.fr/cic/meetings/2015/ICUC9/LongAbstracts /gd2-4-6851222_a.pdf.

Gál, T., B. Bechtel, and L. Unger, 2015: Comparison of two different Local Climate Zone mapping methods. Extended Abstracts, 9th Int. Conf. on Urban Climate/12th Symp. on the Urban Environment, Toulouse, France, Météo-France, 6 pp., www.meteo .fr/cic/meetings/2015/ICUC9/LongAbstracts/gd2-6 -1551002_a.pdf.

Grell, G. A., S. E. Peckham, R. Schmitz, S. A. McKeen, G. Frost, W. C. Skamarock, and B. Eder, 2005: Fully coupled 'online' chemistry in the WRF model. Atmos. Environ., 39, 6957-6976, https://doi .org/10.1016/j.atmosenv.2005.04.027.

Grimmond, C. S. B., and Coauthors, 2010: The International Urban Energy Balance Models Comparison Project: First results from phase 1. J. Appl. Meteor. Climatol., 49, 1268-1292, https://doi .org/10.1175/2010JAMC2354.1.

Hanna, A., J. Ching, and J. Pinto, 2015: Characteristics of heat wave impacts for major cities in the US under current and future climate conditions. Extended Abstracts, 9th Int. Conf. on Urban Climate/12th Symp. on the Urban Environment, Toulouse, France, MétéoFrance, 6 pp., www.meteo.fr/icuc9/LongAbstracts /ccma3-2-7941581_a.pdf.

Hulley, G., S. Veraverbeke, and S. Hook, 2014: Thermalbased techniques for land cover change detection using a new dynamic MODIS multispectral emissivity product (MOD21). Remote Sens. Environ., 140, 755-765, https://doi.org/10.1016/j.rse.2013.10.014.

Imhoff, M. L., P. Zhang, R. E. Wolfe, and L. Bounoua, 2010: Remote sensing of the urban heat island effect across biomes in the continental USA. Remote Sens. Environ., 114, 504-513, https://doi.org/10.1016/j.rse.2009.10.008. Jackson, T. L., J. Feddema, K. Oleson, G. Bonan, and J. T. Bauer, 2010: Parameterization of urban characteristics for global climate modeling. Ann. Assoc. Amer. Geogr., 100, 848-865, https://doi.org/10.1080/00045 608.2010.497328.

Järvi, L., C. S. B. Grimmond, and A. Christen, 2011: The Surface Urban Energy and Water Balance Scheme (SUEWS): Evaluation in Los Angeles and Vancouver. J. Hydrol., 411, 219-237, https://doi.org/10.1016/j .jhydrol.2011.10.001.

Kusaka, H., and F. Kimura, 2004: Coupling a singlelayer urban canopy model with a simple atmospheric model: Impact on urban heat island simulation for an idealized case. J. Meteor. Soc. Japan, 82, 67-80, https://doi.org/10.2151/jmsj.82.67.

—, H. Kondo, Y. Kikegawa and F. Kimura, 2001: A simple single-layer urban canopy model for atmospheric models: Comparison with multi-layer and slab models. Bound.-Layer Meteor., 101, 329-358, https://doi.org/10.1023/A:1019207923078.

Li, D., and E. Bou-Zeid, 2013: Synergistic interactions between urban heat islands and heat waves: The impact in cities is larger than the sum of its parts. J. Appl. Meteor. Climatol., 52, 2051-2064, https://doi .org/10.1175/JAMC-D-13-02.1.

Luvall, J. C., D. A. Quattrochi, D. L. Rickman, and M. G. Estes Jr., 2015: Boundary layer (atmospheric) and air pollution | urban heat islands. Encyclopedia of Atmospheric Sciences, G. R. North, J. Pyle, and F. Zhang, Eds., Vol. 1, Academic Press, 310-318, https:// doi.org/10.1016/B978-0-12-382225-3.00442-4.

Martilli, A., A. Clappier, and M. Rotach, 2002: An urban surface exchange parameterization for mesoscale models. Bound.-Layer Meteor., 104, 261-304, https:// doi.org/10.1023/A:1016099921195.

—, O. Brousse, and J. Ching, 2016: Urbanized WRF modeling using WUDAPT. WUDAPT Doc., 8 pp., www.wudapt.org/wp-content/uploads/2016/05 /Urbanized-WRF-modeling-using-WUDAPT-web -version-March2016.pdf.

Masson, V., 2000: A physically based scheme for the urban energy budget in atmospheric models. Bound.Layer Meteor., 94, 357-397, https://doi.org/10.1023 /A:1002463829265.

—-, and Coauthors, 2014: Adapting cities to climate change: A systemic modelling approach. Urban Climate, 10, 407-429, https://doi.org/10.1016/j .uclim.2014.03.004.

— and Coauthors, 2015: Urban climate, human behavior and energy consumption: From LCZ mapping to simulation and urban planning (the MapUCE project). Extended Abstracts, 9th Int. Conf. on Urban Climate/12th Symp. on the Urban Environment, Toulouse, France, Météo-France, 24 pp., www.meteo.fr /icuc9/presentations/TUKUP/TUKUP3-1.pdf.

—-, and Coauthors, 2017: Architectural archetypes database propositions for WUDAPT. Design to Thrive: Proceedings of the PLEA 2017 Conference, L. Brotas, S. Roaf, and F. Nicol, Eds., Vol. II, PLEA, 1789-1796, https://plea2017.net/.

Mills, G., and Coauthors, 2015: Introduction to the WUDAPT Project. Extended Abstracts, 9th Int. Conf. on Urban Climate/12th Symp. on the Urban Environment, Toulouse, France, Météo-France, 6 pp., www.meteo.fr/icuc9/LongAbstracts/gd2-1-6521222 _a.pdf.

—, B. Bechtel, M. Foley, J. Ching, L. See, and J. Feddema, 2017a: The WUDAPT Project: Status of database and portal tools. 13th Symp. of the Urban Environment, Seattle, WA, Amer. Meteor. Soc., 9.1, 
https://ams.confex.com/ams/97Annual/webprogram /Paper313793.html.

— — - P. Alexander, N. Theeuwes, M. Foley, J. Ching, C. Ren, and X. Yong, 2017b: Using WUDAPT to explore urban exposure to climate risks in selected cities. Design to Thrive: Proceedings of the PLEA 2017 Conference, L. Brotas, S. Roaf, and F. Nicol, Eds., Vol. II, PLEA, 1797-1804, https://plea2017.net/.

Mouzourides, P., A. Kyprianou, and M. K.-A. Neophytou, 2013: A scale-adaptive approach for spatially varying urban morphology characterization in boundary layer parametrization using multi-resolution analysis. Bound.-Layer Meteor., 149, 455-481, https://doi.org/10.1007/s10546-013-9848-4.

— - - M. J. Brown, B. Carissimo, R. Choudhary, and M. K.-A. Neophytou, 2014: Searching for the distinctive signature of a city in atmospheric modelling: Could the Multi-Resolution Analysis (MRA) provide the DNA of a city? Urban Climate, 10, 447-475, https://doi.org/10.1016/j.uclim.2014.04.001.

— _ - R. Choudhary, J. Ching, and M. Neophytou, 2017: How can a multi-scale analysis guide smart urban energy demand management? An example from London City Westminster Borough. Procedia Eng., 180, 433-442, https://doi.org/10.1016/j.proeng.2017.04.202.

Neophytou, M., P. Mouzourides, A. Kyprianou, R. Choudhary, and J. Ching, 2015: Sensitivity of mesoscale models to scale dependent UCP inputs, an example from energy demand. Extended Abstracts, 9th Int. Conf. on Urban Climate/12th Symp. on the Urban Environment, Toulouse, France, MétéoFrance, 6 pp., www.meteo.fr/icuc9/LongAbstracts /nomtm11-4-7021409_a.pdf.

Niyogi, D., S. Bhalachandran, O. Brousse, M. Jain, A. Shreevastava, and A. P. Dimri, 2017: Investigation of the impact of urbanization under the 2015 Delhi heat wave scenario. 13th Symp. of the Urban Environment, Seattle, WA, Amer. Meteor. Soc., 9.6A, https:// ams.confex.com/ams/97Annual/webprogram/Paper 313616.html.

NRC, 2012: Urban Meteorology: Forecasting, Monitoring, and Meeting Users' Needs. National Academies Press, 190 pp., https://doi.org/10.17226/13328.

Oke, T. R., 2006: Initial guidance to obtain representative meteorological observations at urban sites. IOM Rep. 81, WMO/TD-1250, 51 pp., https://library.wmo .int/pmb_ged/wmo-td_1250.pdf.

—, G. Mills, A. Christen, and J. A. Voogt, 2017: Urban Climates. Cambridge University Press, 546 pp., https:// doi.org/10.1017/9781139016476.

Oleson, K. W., G. B. Bonan, J. Feddema, M. Vertenstein, and C. S. B. Grimmond, 2008: An urban parameterization for a global climate model. Part
I: Formulation and evaluation for two cities. $J$. Appl. Meteor. Climatol., 47, 1038-1060, https://doi .org/10.1175/2007JAMC1597.1.

Otte, T., A. Lacser, S. Dupont, and J. Ching, 2004: Implementation of an urban canopy parameterization in a mesoscale meteorological model. J. Appl. Meteor., 43, 1648-1665, https://doi.org/10.1175/JAM2164.1.

Pesaresi, M., and Coauthors, 2013: A global human settlement layer from optical HR/VHR RS data: Concept and first results. IEEE J. Sel. Top. Appl. Earth Obs. Remote Sens., 6, 2102-2131, https://doi. org/10.1109/JSTARS.2013.2271445.

Ren, C., J. Fung, J. Tse, and Y. Xu, 2017: Implementing WUDAPT product into urban development impact analysis by using WRF simulation result-A case study of the Pearl River Delta Region (1980-2010). 13th Symp. of the Urban Environment, Seattle, WA, Amer. Meteor. Soc., 9.2, https://ams.confex.com /ams/97Annual/webprogram/Paper308848.html.

Revi, A., and Coauthors, 2014: Urban areas. Climate Change 2014: Impacts, Adaptation, and Vulnerability. Part A: Global and Sectoral Aspects, Cambridge University Press, 535-612.

Salamanca, F., A. Krpo, A. Martilli, and A. Clappier, 2010: A new building energy model coupled with an urban canopy parameterization for urban climate simulation-Part I. Formulation verification, and sensitivity analysis of the model. Theor. Appl. Climatol., 99, 331-344, https://doi.org/10.1007/s00704 -009-0142-9.

See, L., and Coauthors, 2015: Generating WUDAPT's specific scale-dependent urban modeling and activity parameters: Collection of level 1 and level 2 data. Extended Abstracts, 9th Int. Conf. on Urban Climate/12th Symp. on the Urban Environment, Toulouse, France, Météo-France, 25 pp., www.meteo.fr /icuc9/presentations/GD/GD2-3.pdf.

Stewart, I., and T. Oke, 2012: Local climate zones for urban temperature studies. Bull. Amer. Meteor. Soc., 93, 1879-1900, https://doi.org/10.1175/BAMS -D-11-00019.1.

United Nations, 2014: World urbanization prospects: 2014 revision, highlights. UN Doc. ST/ESA/ SER.A/352, 32 pp., https://esa.un.org/unpd/wup /publications/files/wup2014-highlights.pdf.

Vanegas, C., T. Kelly, B. Weber, D. Aliaga, and P. Mueller, 2012a: Procedural generation of parcels in urban modeling. Comput. Graphics Forum, 31, 681-690, https://doi.org/10.1111/j.1467-8659.2012.03047.x.

—, D. Aliaga, B. Bedrich, and P. Waddell, 2012b: Inverse design of urban procedural models. ACM Trans. Graphics, 31 (6), 168, https://doi.org/10.1145 /2366145.2366187. 
Verdonck, M.-L., A. Okujeni, S. van der Linden, M. Demuzere, R. De Wulf, and F. Vancoillie, 2017: Influence of neighbourhood on 'Local Climate Zone' mapping in heterogeneous cities. Int. J. Appl. Earth Obs. Geoinf., 62, 102-113, https://doi.org/10.1016/j .jag.2017.05.017.

Wang, X., and W. Dai, 2015: Development of fine-scale urban canopy parameters in Guangzhou city and its application in the WRF-Urban model. Extended $A b$ stracts, 9th Int. Conf. on Urban Climate/12th Symp. on the Urban Environment, Toulouse, France, MétéoFrance, 6 pp., www.meteo.fr/icuc9/LongAbstracts /gd5-2-3221289_a.pdf.

WMO, 2015: Establishing a WMO cross-cutting urban focus. Seventeenth World Meteorological Congress, Doc. WMO-1157, Resolution 68(CG-17), 560, www .wmo.int/aemp/sites/default/files/wmo_1157_en.pdf.

Wouters, H., M. Demuzere, U. Blahak, K. Fortuniak, B. Maiheu, J. Camps, D. Tielemans, and N. P. M. van Lipzig, 2016: The efficient urban canopy dependency parameterization (SURY) v1.0 for atmospheric modeling: Description and application with the COSMOCLM model for a Belgian summer. Geosci. Model
Dev., 9, 3027-3054, https://doi.org/10.5194/gmd-9 $-3027-2016$.

Xu, Y., C. Ren, P. Ma, J. Ho, W. Wang, K. K.-L. Lau, H. Lin, and E. Ng, 2017a: Urban morphology detection and computation for urban climate research. Landscape Urban Plann., 167, 212-224, https://doi .org/10.1016/j.landurbplan.2017.06.018.

,$- \ldots$, M. Cai, and E. Ng, 2017b: Issues and challenges of remote sensing-based local climate zone mapping for high-density cities. 2017 Joint Urban Remote Sensing Event, Dubai, United Arab Emirates, IEEE, https://doi.org/10.1109/JURSE.2017.7924558.

Zhang, N., Z. Gao, X. Wang, and Y. Chen, 2010a: Modeling the impact of urbanization on the local and regional climate in Yangtze River Delta, China. Theor. Appl. Climatol., 102, 331-342, https://doi .org/10.1007/s00704-010-0263-1.

Zhang, Y., X. Wen, and C. Jang, 2010b: Simulating chemistry-aerosol-cloud-radiation climate feed back over the continental U.S. using online-coupled Weather Research Forecasting Model with chemistry (WRF/ Chem). Atmos. Environ., 44, 3568-3582, https://doi .org/10.1016/j.atmosenv.2010.05.056.
A Scientific Peak: How Boulder Became a World Center for Space and Atmospheric Science

\section{Joseph P. Bassi}

0 nce a Wild West city tucked between the Rocky Mountains and the Great Plains, Boulder is now home to some of the biggest names in science, including NCAR, NOAA, and NIST.

Why did big science come to Boulder? How did Boulder become the research mecca it is today?

A Scientific Peak is a fascinating history that introduces us to a wide variety of characters, such as Walter Orr Roberts, and the serendipitous brew of politics, pas. sion, and sheer luck that, during the post.WWII and Cold War eras, transformed this "scientific Siberia" into one of America's smartest cities.

(C) 2015, 264 pages, paperback

print ISBN: 978-1-935704-85-0 eISBN: 978-1-940033-89-1 List price: $\$ 35$ AMS Member price: $\$ 25$

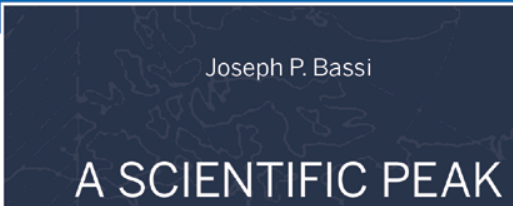

A SCIENTIFIC PEAK

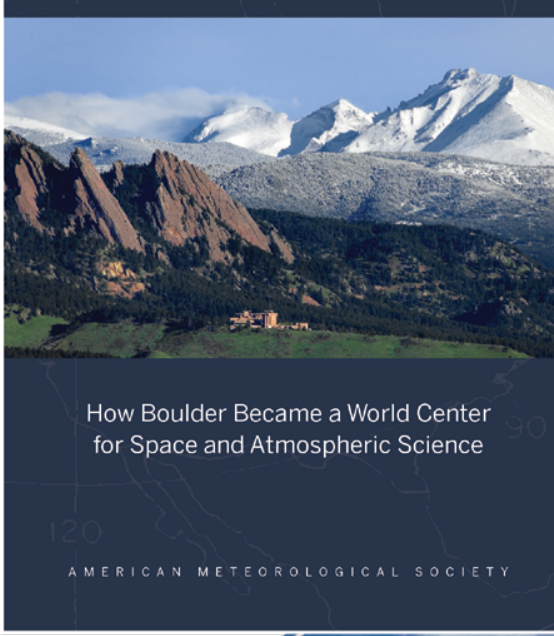




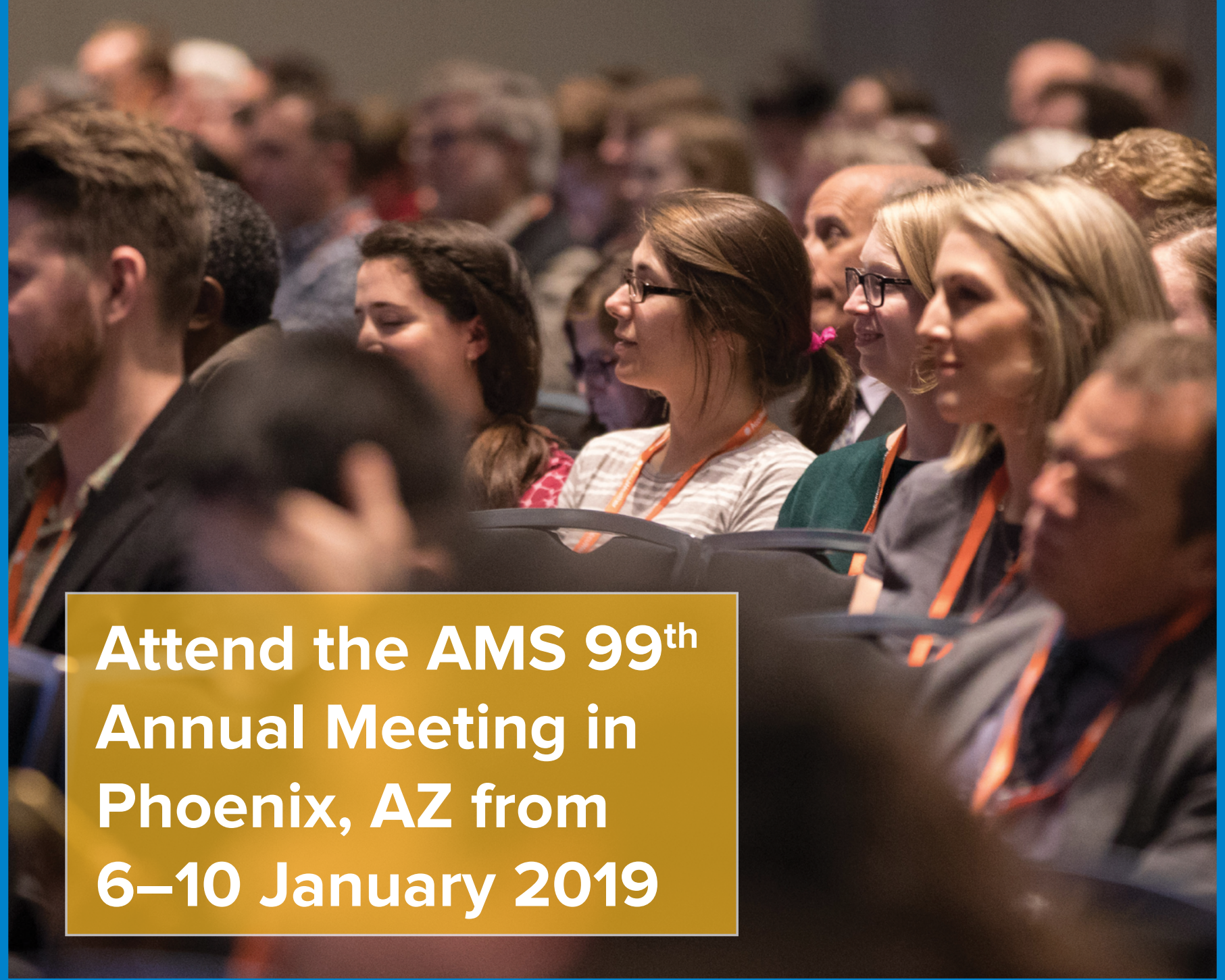

This year's theme is

Understanding and Building Resilience to Extreme Events by Being Interdisciplinary, International, and Inclusive (III)

Don't miss 30+ conferences and symposia, networking opportunities, short courses, and hundreds of exhibitors. Early registration deadline is 1 December.

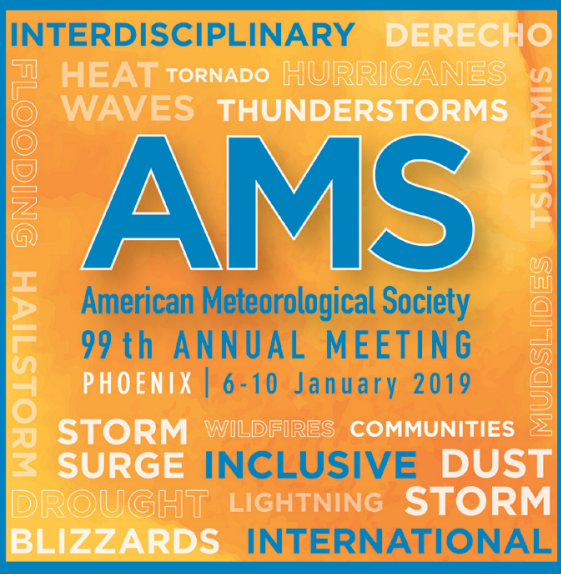

annual.ametsoc.org/2019 


\section{AMS BOOKS RESEARCH APPLICATIONS HISTORY}

The Thinking Person's Guide to Climate Change ROBERT HENSON

This fully updated and expanded revision of The Rough Guide to Climate Change combines years of data with recent research. It is the most comprehensive overview of climate science, acknowledging controversies but standing strong in its stance that the climate is changing-and something needs to be done.

(c) 2014, PAPERBACK, 520 PAGES,

ISBN: 978-1-935704-73-7

LIST \$30 MEMBER \$20
CLIMATE

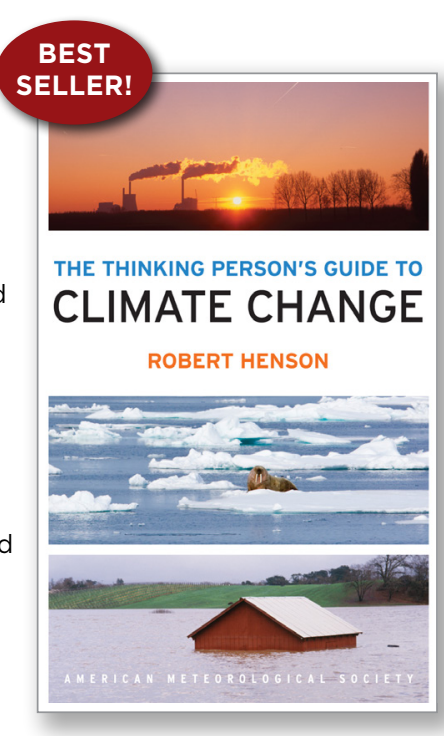

\section{Climate Conundrums:} What the Climate Debate Reveals about Us

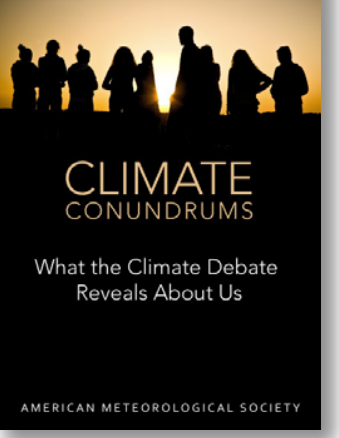

WILLIAM B. GAIL

This is a journey through how we think, individually and collectively, about humanity's relationship with nature, and more. Can we make nature better? Could science and religion reconcile? Gail's insights on such issues help us better understand who we are and find a way forward.

(c) 2014, PAPERBACK, 240 PAGES, ISBN: 978-1-935704-74-4 LIST \$30 MEMBER \$20

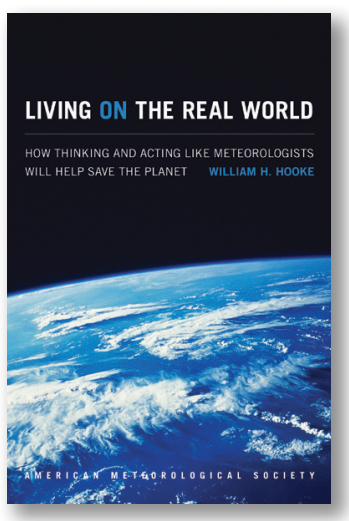

\section{Living on the}

\section{Real World:}

How Thinking and Acting Like Meteorologists

Will Help Save the Planet WILLIAM H. HOOKE

Meteorologists focus on small bits of information while using frequent collaboration to make decisions. With climate change a reality, William $\mathrm{H}$. Hooke suggests we look to the way meteorologists operate as a model for how we can solve the 21st century's most urgent environmental problems.

(c) 2014, PAPERBACK, 272 PAGES, ISBN 978-1-935704-56-0 LIST \$30 MEMBER \$22

\section{Synoptic-Dynamic Meteorology Lab Manual:}

Visual Exercises to Complement Midlatitude Synoptic Meteorology

\section{GARY LACKMANN, BRIAN E. MAPES, AND KEVIN R. TYLE}

These labs link theoretical concepts with groundbreaking visualization to elucidate concepts taught in the award-winning companion textbook by Gary Lackmann, Midlatitude Synoptic Meteorology.

(c) 2017, PAPERBACK, 126 PAGES, ISBN 978-1-878220-26-4 LIST \$80 MEMBER \$60 STUDENT \$50

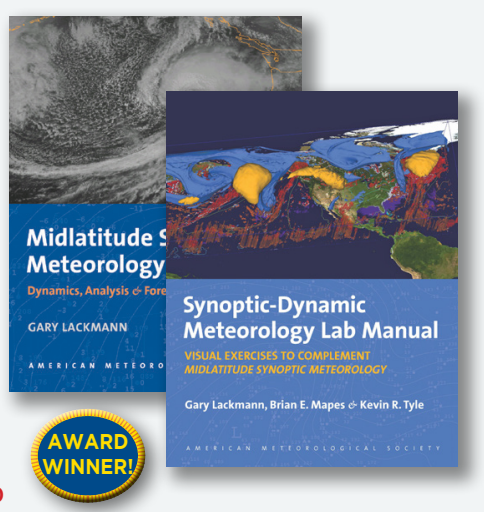

\section{GUIDES}

\section{An Observer's Guide to Clouds}

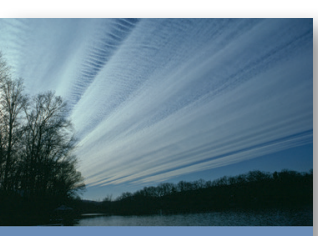

AN OBSERVER'S GUIDE CLOUDS AND WEATHER A NORTHEASTERN PRIMER ON PREDICTION TOEY GARISON, PAUL KNIGH, ANO GELLA WYCKOFF

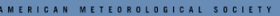
and Weather:

A Northeastern Primer on Prediction

TOBY CARLSON, PAUL KNIGHT, AND CELIA WYCKOFF

With help from Penn State experts, start at the beginning and go deep. This primer, intended for both serious enthusiasts and new meteorology students, will leave you with both refined observation skills and an understanding of the complex science behind the weather: the ingredients for making reliable predictions of your own. It connects fundamental meteorological concepts with the processes that shape

weather patterns, and will make an expert of any dedicated reader.

(c) 2014, PAPERBACK, 210 PAGES,

ISBN: 978-1-935704-58-4 LIST \$30 MEMBER \$20

\section{Eloquent Science:}

A Practical Guide to Becoming a Better Writer, Speaker, and Atmospheric Scientist DAVID M. SCHULTZ

The ultimate communications manual for undergraduate and graduate students as well as researchers in the atmospheric sciences and their intersecting disciplines.

(C) 2009, PAPERBACK, 440 PAGES, ISBN 978-1-878220-91-2

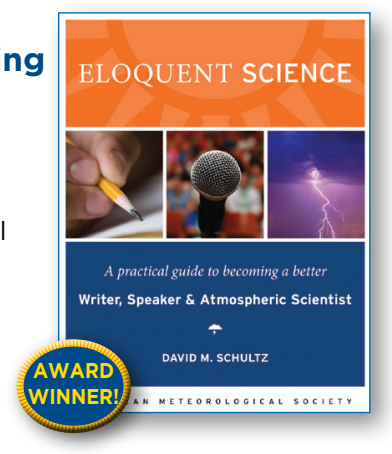

LIST \$45 MEMBER \$30 


\section{SHIPPING + DISCOUNTS AT BOOKSTORE.AMETSOC.ORG}

NEW

Verner Suomi: The Life and Work of the Founder of Satellite Meteorology

JOHN M. LEWIS WITH JEAN M. PHILLIPS, W. PAUL MENZEL, THOMAS H. VONDER HAAR, HANS MOOSMÜLLER, FREDERICK B. HOUSE, AND MATTHEW G. FEARON

Born in a Minnesotan mining town, Suomi would spend his best years next door in Wisconsin, but not before seeing the whole world-from space, that is. This is the story of the scientist, inventor, and teacher who founded satellite meteorology, written by members of the communities that grew up around his groundbreaking work.

LIST \$3O MEMBER \$20

(c) 2016, PAPERBACK, 240 PAGES, ISBN: 978-1-944970-22-2

\section{Weather in the Courtroom: Memoirs from a Career iForensic Meteorology}
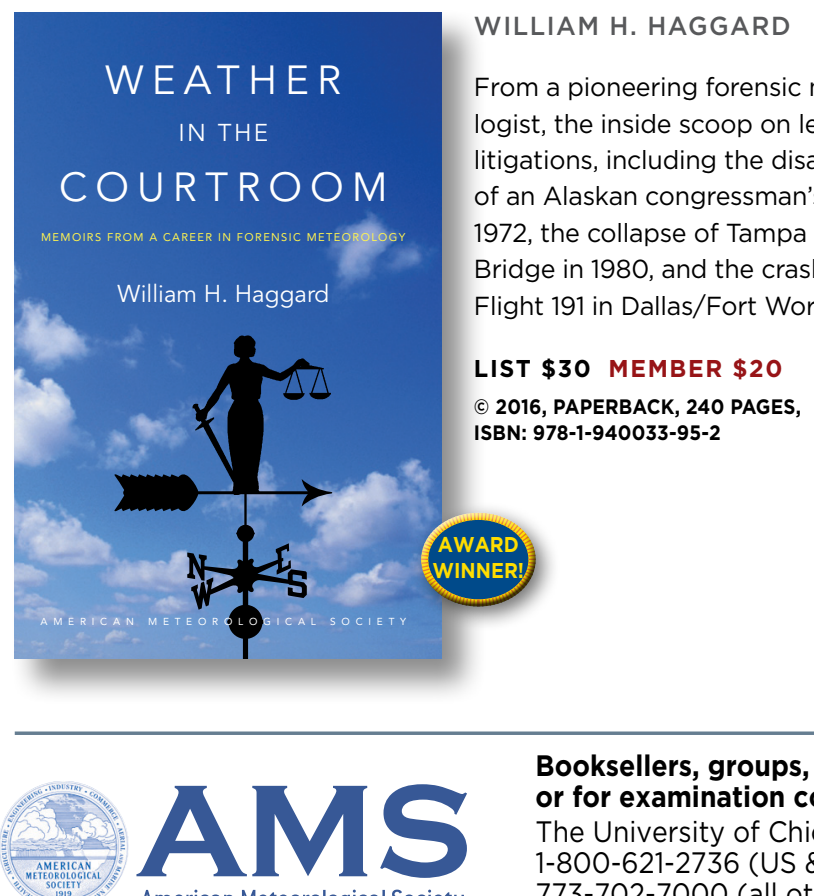

American Meteorological Society

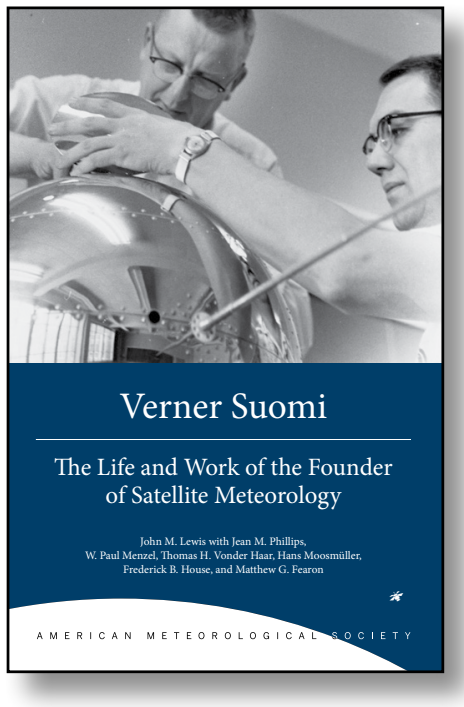

HISTORY

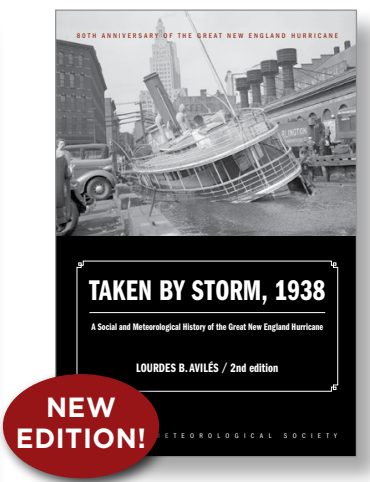

Taken by Storm, 1938:

A Social and Meteorological History of the Great New England Hurricane, 2nd Ed. LOURDES B. AVILÉS

The science behind 80TH
ANNIVERSARY OF STORM the 1938 Hurricane, which hit New England unannounced, is presented here for the first time along with new data that

sheds light on the motivations of the Weather Bureau forecasters. This compelling history successfully weaves science, historical accounts, and social analyses to create a comprehensive picture of the most powerful and devastating hurricane to hit New England to date.

(c) 2018, PAPERBACK, 288 PAGES, ISBN: 978-1-944970-24-6 LIST \$30 MEMBER \$20

\section{A Scientific Peak:}

How Boulder Became a World Center for Space and Atmospheric Science

JOSEPH P. BASSI

How did big science come to Boulder, Colorado? Joe Bassi introduces us to the characters, including Harvard sun-Earth researcher Walter Orr Roberts, and the unexpected brew of politics, passion, and sheer luck that during the Cold War era transformed this "Scientific Siberia" to home of NCAR and NOAA

(c) 2015, PAPERBACK, 264 PAGES, ISBN: 978-1-935704-85-0 LIST PRICE: $\$ 35.00$ MEMBER PRICE: $\$ 25.00$

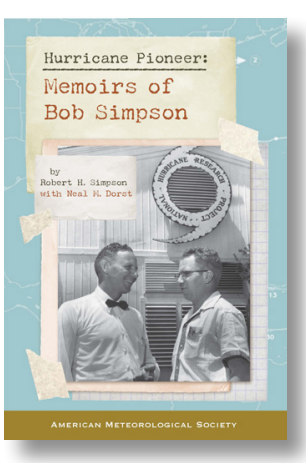
Hurricane Pioneer: Memoirs of Bob Simpson ROBERT H. SIMPSON AND NEAL DORST

In 1951, Bob Simpson rode a plane into a hurricane-just one of the many pioneering exploits you'll find in these memoirs. Bob and his wife Joanne are meteorological icons: Bob was the first director of the National Hurricane Research Project and a director of the National Hurricane Center. He helped to create the Saffir-Simpson Hurricane Scale; the public knows well his Categories 1-5. Proceeds from this book help support the AMS's K. Vic Ooyama Scholarship Fund.

(c) 2015, PAPERBACK, 156 PAGES

ISBN: 978-1-935704-75-1 LIST \$25 MEMBER \$2O 


\section{Attention AMS Student Members}

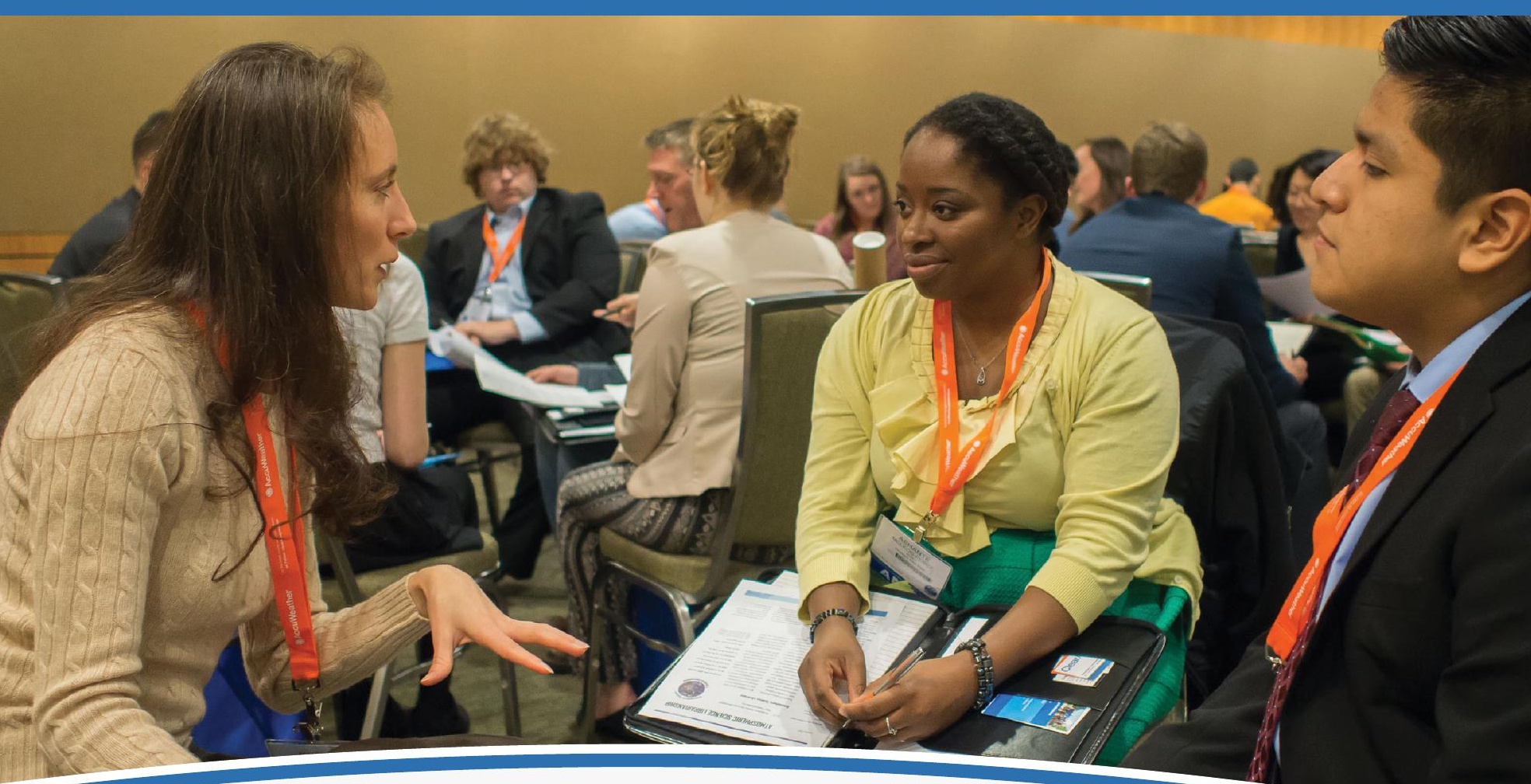

Stay connected to AMS after graduation for half the regular membership rate

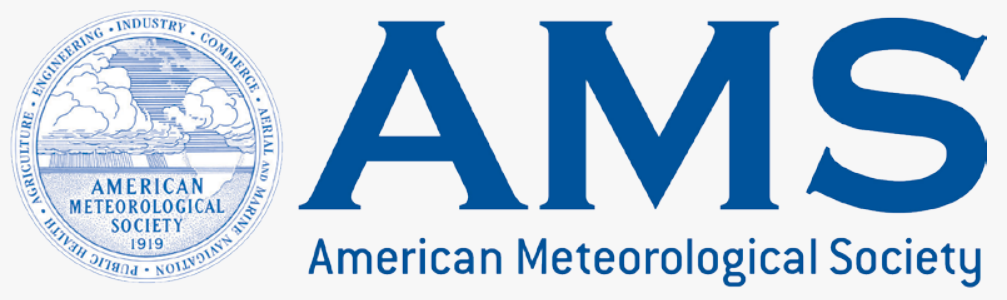

Let AMS help you build your expertise, your network, your career. There's never been a more important time to be a member. 